\title{
Ç I N E K O N O M İ S I*
}

Yazan : Nicholas BRUNNER

Çeviren : As. Dr. Ahmet Y. GöKDERE

\section{ÖNSÖZ**}

Günümüz dünyasında bazı en önemli ve ilginç gelişmelerin Çin'de yer almasına karşılık, ülkemiz halkı bunlara ait çok az şey duymakta; duyulanlar ise, kavrayamama ve düşmanhk yüzünden tahrif edilmektedir. Iște bu yazının amacı, çağdaş Çin hakkında basit ve temel bilgiler vermektir.

Bugün, az gelişmiş ülkelerin sorunlarn ile artan açlk ve yoksulluk tehdidi üzerinde geniş bir tartışmanın varlığına rağmen, bu sorunun dünya nüfusunun dörtte biri yönünden çözümlenmekte olduğundan pek seyrek söz edilmektedir.

Çin'in kalkınmayı gerçekleștirmede izlediği yöntem, herkesi iş başına çağırmak ve herkesin çalışabileceği koşulları yaratmaktır. Tüm ülkeyi kapsayan toprak reformu, eski toprak sahiplerini hayatlarını kazanmak üzere çalışmaya; topraklarını, önceki yoksul köylüler ile topraksız işçilerin çalışma alanı bulabileceği biçimde yeniden dağıtmaya zorlamıștır. Tarım, giderek kooperatifler halinde örgütlendi. Halen üretimin temel birimi, «takım» denilen, belirli bir toprak parçasının mülkiyetine sahip ve gelirini bunu iş. lemekle kazanan kü̧̧ük bir topluluktur. Ölü mevsimlerde, ișler daha geniş birim olan "komün» tarafundan düzenlenerek toprak ıslahı, sulama, kurutma, teraslama vb. yapılır. Böylece, köylülere, gelecekte ailelerini daha iyi beslemek üzere, hemen hemen çıplak

* Bu makale, Anglo-Chinese Educational Institute'un izniyle («China’s Economy" Yorkshire, Great Britain 1969) isimli yayından çevrilmiştir. Çeviri ve yaym izni verdikleri için, adı geçen kurum yöneticilerine teşekkür ede. rim. A, G.

** Önsöz, Cambridge Universitesi ekonomi profesörlerinden Joan Robinson tarafından kaleme almmıştır. 
elleriyle nasıl servet yaratabilecekleri; endüstriyi destekleyici tarımsal fazlayı artırarak ülke zenginliğine nasıl katkıda bulunabilecekleri gösterilir.

Ağır endüstri, Sovyetler Birliği'nin halen ödenmiş bulunan bir miktar bașlangıc yardımı ile fabrika, atelye, kara ve demiryolları. na endüstrideki işyeri sayısını artıracak biçimde yapılan yatırımlarla yeniden kuruldu ve genişletildi. Modern sermaye malları ile donatılamayan issgücii ise, Çinlilerin sher iki ayak üzerinde birden yürüme» dedikleri ilkeye uygum olarak küçük sanat kooperatiflerince kullanıld.

İstihdam seviyesinin yükseltilmesi tek sorun değildir. İyileştirilmiş tekniklerle verimliliği yükseltmek de gerekir. Bu nedenle, yeni yöntemler uzmanlarca ögretilmekle yetinilmeyip; köylü ve işçiler denemeler yapmaya, iyileștirmeler bulmaya ve bunları sinamaya özendirilmektedir. Bilimsel davranıșı günlük hayata sokmak, yalnız okul-içi öğretim gibi biçimsel değil, siyasal davranıs. ları da içeren geniş anlamda öğrenimi gerektirir.

«Siyasayı Hizmete Koyma» deyimi bizlere bazen düzeni bozucu görünür. Siyasa, bizim için dar ve anlaşmazllk doğurucu bir anlam taşır. Çin'de ise, siyasa, daha çok topluma karșı sorumluluk duygusudur. Kendisi için bir șey kazanmayı düșünmeden, sosyalizmi kurmak üzere kolla yada kafayla çalışmaktır. Siyasa, yaşlı entellektüeller ile orta sinfftan kestirme yoldan bir seçkinler kadrosu oluşturmaktan çok; eğitimi, yoksul ve okumamış ailelerin çocuklanna açarak halkın tümünün yeteneklerine dayanma örneğinde olduğu gibi, geleceğe ait kararlar almayı da ifade eder.

Nìtekim, tamamen yetiştirilmiş uzman işçilere dayanmak yerine, düz işçilerin teknik gelișme sürecine sokulması, șimdiden göze çarpan başarılar yaratmış̧ır. Tarım temel, endüstri öncü etkendir. Çin yöntemi, hayat standardı giderek yükselirken, geniş bir endüstriyel yatırım seviyesinin gerçekleștirilmesi olanağı da vermektedir. 1968 yllinda yeni hidro-elektrik tesisleri, yeni kömür yatakları ve petrol kuyuları açılmasının sağladığı üretim gücü arıșı ile demir-çelik endüstrisinin genişletilmesi ve kimya endüstrisindeki son gelişmeler, endüstriyel ilerlemede yeni bir sıçramanın temellerinin atılmakta olduğunu gösteriyor. Üretim gücündeki söz konusu artış ise, tarım ile hafif endüstrideki makineleşme hızının artmasını sağlayacaktır. Ișçilerin, özellikle Kültür Devrimi'nden bu yana ortaya çıkan büyük üretim şevki, denemelerin özendiril- 
mesi ve eğitilmiş teknisyenlerin niteliksiz işçilerle yakın işbirliği yapması, verimliliği yükseltmiştir. Ưretim yönteminde, çeșitli önemdeki iyileştirmeler, sürekli olarak yapılmaktadır. Böylece, Çin teknolojisi, bir-iki üretim dalında dünyada en ileri seviyeye erişmiştir.

Işe çağırma ve istihdamın düzenlenmesi, yalnız açlık ve yoksulluğu yenmesi, bazılarına lüks temininden önce herkese gösterişsiz bir konfor sağlaması yönünden değil, kendi kendine saygı yaratmasından dolayı da önemlidir. Ínsanları «halka hizmet» için ișe çağırma «özendirme primleri» sunmaktan çok daha doyurucu ve etkindir. Bu ilke "sosyal hizmet» sayabileceğimiz sahalarda da geçerlidir. Yașh ev hanımları basit ïretim için kooperatifler kurmaya özendirilir; kör ve sağırlar, yeteneksizliklerini yenecek biçimde düzenlenmiş özel atelyelere sahiptir. Bunların gayrı safî millî hasılaya katkıları fazla değilse de kendi morallerine katkılan büyüktür. Çin'de, bunlar dışında, geniş ölçüde ders alabileceğimiz daha pek çok ekonomik ve sosyal deneme yapılmaktadır. Ne var ki, Batı basınınca yapılan kadar Sovyetler Birliği'nin düşmanca propagandası da Çin'de neler olduğunu öğrenmemizi engellemektedir. Mamafih, Çin'in az gelişmiş denilen ülkeler arasında genel hayat standardının, dışarıdan "yardım» alınmaksızın yükseldiği, borçlarını ödemiș ve dış ticareti dengede bulunan tek iulke haline geldiği artık kimse tarafından yadsınamyacağından, sürekli olarak çökme ve yıkılmayı öngören söz konusu propaganda, inandırıcılı̆̆ını giderek kaybetmektedir. Benzer şekilde, bu üllsedeki askeri ilerlemenin her hangi bir işgali önleyici biçimde tasarlandığı; Çin siyasasının, tehdit ve kıskırtmaları dikkate değer bir sükunetle geçiştirmek olduğu Çin'e karşı fazla sempati duymayan strateji uzmanlarınca bile kabul edildiği halde bu ülke, dünyaya, saldırıya yönelmiş bir tehdit olarak tanıtılmıștır.

Bu yazmın amacı, okuyucuyu kime inanacağını saptamak üzere temel bilgilerle donatmaktır.

\section{G I R i s}

Çin Halk Cumhuriyeti'nin ekonomik gelişmesi, iki nedenle ilginç ve önemlidir. Ilkin, insanoğlunun bir çeyreğine yakm bölümü Çin'de yașadığından, burada olanlar insanlığın geri kalan bölümünüi ilgilendirecektir. Ikinci olarak, Çin'lilerin iyi bir hayat standardı elde etme yolunda karşılaştıkları probiemler, Asya, Af- 
rika ve Latin Amerika gibi halklarının yoksulluktan kurtulmak için savaştıkları ülkelerinkilere benzemektedir. Çin denemesi, bu yüzden, dünya yüzündeki insanların hayallerì ile ilgilidir.

Ne yazık ki, Çin konusu, hak ettiği ilgiyi çekememiştir. Çin ekonomisi hakkında, bu yazıda da yararlanılmış olan bazı sıhhatli ve bilimsel çalışmalar bulunmakla birlikte, halka inmiş seviyelerde, geniş ölçüde yanlış yorumlama yapılmıştır. Dikkat, hata ve başarısızlıklar uizerine çekilmiş̧tir. Her hangi bir başarıyı küçümseme ve Çin denemesinden yapıcı seyler öğrenilemiyeceğini ima etme yolunda bir eğilim doğmuștur. Örneğin, genellikle Çin öncülerinin doğmatizminin ekonomik gelișmeyi ciddî șekilde engellediği söylenir. Aynı görüş çerçevesinde, ideoloji uygulanabilirlikle çatıșma halindedir. Bu durum Çin ekonomi siyasasında en ciddi başarısızlıkların ortaya çıktığı tarım alanında açıkça görülebilir.

Bu yazınm amaçlarından biri, yukarıda belirttił̧imiz yorumu tartı̧̧mak ve altında yatan olayları değerlendirmektir. Ancak, böylesi bir çözümlemeye girişmeden önce, mevcut bilgi kaynaklarına da değinmek gerekir. Bunlar, Çin hükümetince yayınlanan bilgiler ile Çin'de seyahat edenlerin raporları olmak üzere iki gruptur. İkinci grup bize resmî istatistikleri tartabileceğimiz kaba bir ölçü verir. Bunlar Çin'i 1949 'dan önce tanıyan ve kırsal bölgeleri gezme fırsatını bulmuş yazarlarca kaleme alındığında, ayrı bir değer kazanırlar.

Söz konusu raporların başlıca ortak noktası, 1949'dan beri Çin hayat standardının yükselmekte olduğudur. Zaten, makul bir insanın bu gerçeği yadsıması beklenemez.

Gelişmenin ölçeği hakkında fikir edinmek için resmî istatistiklere bakmalıyı. Batı bilim adamlarının genel görüșiu, bunlarm, bütün diğer istatistikler gibi yorumlamayı gerektirmekle birlikte, gerçeğe ulaşmak üzere yapılmış iyi niyetli girişimleri temsil etme anlamında, güvenilir olduğu yolundadır. Yetkililer, faraza 1957 yllinda çelik üretiminin 5,35 milyon ton olduğunu söylerlerse, bunu yetkililerin verebileceği en shhatli rakam olarak kabul etmeliyiz. Şüphesiz, bütün istatistikler hataya konu teșkil eder. Modern istatistik servislerinin henüz gelişmekte olduğu yoksul ülkelerde tarımsal çıtıyı kesinlikle ölçmek özellikle güçtür. Tarımdaki iyi niyetli hata payımın geniș ölçekli endüstridekinden daha fazla bulunmasi olasidir.

Ancak, temel rakamların makul ölçülerde sıhhatli olduğu konusunda tatmin olsak bile, başka bir güçlük vardır. Endüstrinin, 
tarımın ve bir bütün olarak ekonominin genel icraatının her hangi bir ölçüsüne sahip olmak şüphesiz ki arzu edilir. Eğer, 1949'dan beri bütün malların çıtılarında aynı oranda artıșlar olmuş, yeni mamuller çıkartılmamış, malların nispî fiyatları aynı kalmış olsaydı; bir problem doğmayacaktı. Ne var kí, sayılanların hiç biri böyle değildir. Ekonomik kalkınma süreci sırasında bazı sektörler diǧerlerinden daha hızlı gelişir, önceden üretilmeyen bazı mallar üretilmeye başlanır ve fiyatlar değişir. Ekonominin şu veya bu hızla kalkındığı söylendiğinde, ele alınan dönemde ortaya çıkmış binlerce çeşit değişme tek bir rakamda toplanmaya çalıșllmaktadır. $\mathrm{Bu}$ değișmeler, tüm ekonomik yapının dönüișüm halinde olduğu zamanlardaki gibi hızlandığında, tek bir rakam daha da anlamsızlaşacaktır. Bütün bu uygulama ve kavram güçlüklerine rağmen, Çin'deki ekonomik kalkınmanın büyüklü̈̆̈u hakkında, hiç olmazsa 1958 yılına kadar, bir fikir edinme olanağı yine de vardır.

Bu tarihten sonra Çin makamları, istatistik servislerinde ekonominin yönetimine yardımcı olmak üzere girişilen iyileştirme çabalarına rağmen, toptan rakamlar yayınlamayı bıraktılar. 1958'den sonraki bazı yıllar için kimi malların üretim miktarlarını gösteren rakamlar varsa da bunlar bölïk pörçük durumdadır. Ekonominin genel icraatı hakkındaki tahminler ise yalnxzca doğruluğu şüpheli rakamlar olarak alınabilir. Ne var ki, daha fazla rakam şüphesiz arzu edilmekle beraber bu yazının başlıca amac1, istatistikî bir temrin olmayıp Çin hükümetinin ekonomik gelişmeyi planlamasında karşılaștığı problemler ile bunların çözümünde benimsenen yöntemlerin incelenmesidir.

\section{TOPLUMSAL VE KÜLTÜREL YAPI}

Çin'de çok eski zamanlarda kurulan ve 20 . asırdaki nihâ̂ yıkılmasına kadar süregelen toplum biçimi, genellikle feodalizm olarak betimlenir. Çin feodalizmi Avrupalı türlerinden birçok yönlerden ayrilmakla birlikte zenginlik, toplumsal statü ve siyasal gücün toprak mülkiyetine dayandığı bir toplumu ifade etmesi açısından bunlara benzerlik göstermektedir. Çin'de tarımın başarılı olması, bütün diğer şeyler dıșında su arzının denetlenmesini gerektirir. Akarsuların taşması engellenmeli ve bunlar sulamayı sağIlyacak güçler durumuna getirilmelidir. Bu ise, büyük-ölçekli kamu işlerine el atabilecek, güçlii bir merkezî organı gerektirir. Çin toplumu kendisini, asırlar boyunca, dikkate değer bir başarıyla bu duruma uyarlamıștır. Durgunlaşmadan uzak șekilde, bilim ve 
teknolojide hayli ilerleme yapmıs; dünyanın takdir ettiği bir sanat ve kültür yaratmış̧ır. Nüfus, özellikle 17. asırdan sonra durmadan artmıştır. Kuzeyden gelen göçebe işgalciler ele geçirilmiș yada püskürtülmüştür. Ancak, Çin toplumunun başarısı, kırsal bölgelerdeki hassas bir kuvvet dengesine dayanmaktadır. Toprak sahibi olan sınıf etkin bir yönetim gösterip sulama ve taşkınları denetleme sistemini iyi durumda muhafaza ettiği, vergileri makul seviyelerde tuttuğunda, köylüler toprak kiraları ile faizlerini ödemeye devam etmekteydiler. Çin'de aslında ticarî olan ekonomik ilişkiler, belirli geleneksel inançlarla hafifletilirdi. Örneğin, kıtllk zamanlarında toprak sahipleri verdikleri kredinin faizini bağışlamak ve ihtiyaç içinde olanlara ambarlarından bedava hububat vermek zorundaydı. Merkezî güç zayıfladığı yada zor kullanarak almada ileri gittiği, borca karşılık mallara el koyduğu; toprak sahipleri geleneksel olarak doğru sayllan biçimde davranmadığında, maliyeti yüksek ve tatlılıkla önlenmesi gựç olan köylu ayaklanmalarını ortaya çıkması olasıydı. Çin tarihi böylesi ayaklanmalarla doludur. Böyle zamanlarda, köylü kafasındaki, ne zengin ne de yoksulun bulunduğu hür ve eşit insanlarm toplumu düşüncesi açığa çıkmaktaydı. Bu feodal toplum, 19 ve 20 . asırlarda emperyalizmin etkisi ve kapitalist endüstri denilen yeni bir ekonomik düzenlenme biçiminin gelişiyle nihayet parçalandı. Çin devrimi, bir yandan sonuncu ve en büyük köylü hareketi; öte yandan, bütün öncekilerden farklı bir devrim olarak düşünülebilir. Gerçekten, hemen bütün diğerlerinden farklı olarak, başarıya ulaşmıștır. Ustelik, Çin toplumunun bütününün yeniden düzenlenmesini amaçlamıs ve bunu gerçekleștirmiştir.

\section{MODERN DÖNEMDE EKONOMİK DURUM (1900 - 1949)}

Her endüstri-öncesi toplumda olduğu gibi Çin'de de, tarım milli gelirin büyük böltimünü sağlayan ve nüfusun $\% 80$ kadarını istihdam eden en önemli sektördü. Çin halkı, tarih içindeki yayılması sırasında, geniş ölçüde arazi ıslahı yapmaksızın ekime hazır toprakların tamamıı kullanma yoluna gitti. Çin'in büyük bir kıs. mı dağlı yada çöl olduğundan, ekilen topraklar ülke topraklarının ancak \% 10 kadarımı teşkil etmektedir. Ülkenin bazen Asıl Çin «China Proper» denilen, nüfusun büyük bölümünün yaşadığı do. ğu kesimi, Yangçe nehri sınır olmak üzere başlıca iki coğrafî bölgeye ayrilabilir. Kuzeyde ana ürün buğdaydır. Bunun yanısıra akdar1 ve diğer iri taneli tahıllar da yetiştirilir. Pamuk ve soya fa- 
sulyesi önemli endüstriyel ürünlerdir. Güneyde başlıca ürün pirinçtir. Burada hububat üretimini çay ve tropik ürünler ile muz gibi meyvalar destekler.

Arazinin büyük kısmı, ikinci tür ürünlere ayrılmıștı ve halen de böyledir. Gelir seviyesinin düșüklügüünden, kaynaklar davar otIatılması ve geniş çapta et üretimi için ayrlamamıştır. Öte yandan, Çinlilerin sütten iğrenmeleri, sütle ilgili tarımın da ihmal edilebilir olduğunu gösterir.

1949 öncesinde Çin, bir toprak sahipleri ülkesi olduğu halde geniş araziler ülkesi değildi. 90 dönüm * kadar toprağı olan kimse dikkate değer varlı̆̆a sahip sayılırdı. Oysa, İngiltere'de ayn büyüklükteki bir çiftlik küçük saylmaktaydı. Rusya ve Doğu Avrupa ile 18-19. asırlarda Ingiliz asillerinin büyük arazi sahipliğinin benzerine Çin'de rastlanmamaktaydı. Kaldı ki, ekilen arazi birimi, her ne kadar mülkiyet birimi değilse de, aile çiftliği olarak kalmıștır. Yani, toprak sahibi, arazisini bütünlenmiş bir girişim olarak işletme yoluna gitmemekte; 7-8'er dönümlük parçalara ayirarak isteyen ailelere kiralamaktaydı. Baba toprağım ogullar arasında eşit olarak paylaştıran Çin miras hukuku da, çok büyük arazilerin ortaya çıkmasını engellemiștir. Öte yandan, bir zamanlar, faraza, ortaçăg Avrupa feodalizminden ileri bulunan tarımsal teknoloji de, modern ölçülere göre son derece geri kalmıştı. Batı-tarıminda niteliksel değişme yapan bilimsel ilerlemeler bu ülkeye erișemediğinden, kişi ve dönüm başına çıktı çok düş̧üktü. Batıda, işgưcił ve toprağın verimliliğini bu derece yükselten bitki biolojisi, yapma gübreler ve makineleşme Çin'de bilinmemekteydi. Ustelik, tarımın toplumsal örgütlenmesi de daha modern yöntemlerin benimsenmésine karșı durumdaydı. Böylece, bir sınıf olarak top. rak ağalarının geleneksel hayat biçimi fosillești.

Aylak ve asalak; çevrelerinde doğan hoşnutsuzluğun farkına vardıkları halde kendilerini çağcıl dünyaya uyarlayamayan bir grup olarak rant ve faiz kazançları ile geçinmeye devam ettiler. Japon. yalı toprak sahiplerinin aksine, yeni teknolojiyi benimseme ve Çin ekonomisini çağc1l duruma getirme yeteneğine sahip değillerdi. $\mathrm{Bu}$ yüzden, bir sınıf olarak ortadan kaldırılmalarını önleyemediler.

Çin komünistleri, köylüleri yoksul, orta ve varlıklı olmak üzere ïç gruba ayırdı. Yoksul köylüler, hiç yada pek az toprağa sa-

* Metinde «20 acres» olarak geçmektedir. 1 acre $=4,39$ dönüm (Ç. N.) 
hip, toprak ağalarından arazi kiralayarak yaşamak zorunda bulunanlardı. Orta gelirli köylüler, kendi işgü̧̧leri ile işlediklerinde geçinebilecekleri büyüklükte toprağa sahiptiler. Varlıklı köylülerin ise, bizzat ekebileceklerinden fazla toprakları vardı ve yardımcı iş̧̧i kullanırlardı. Ancak, bu gruplarm oranları, ülkenin çeşitli kesimlerinde birbirinden farklıydı. Kiracıllk, Güney'de Kuzey'den daha yaygındı. 1932 yılında yazan Tawney, Güneydeki köylülerin üçte iki yada daha fazlasının kiracı olduğunu ileri sürmüștür. Mao' nun memleketi olan Hunan'da bu oran $\% 80$ kadard. Kuzey'de ise ișlediği toprağa sahip olanlann oranı daha yüksekti. ${ }^{1}$ Ancak, böylesi toptan rakamların yanıltıcı olabileceği unutulmamalıdır. Arazi niteliğinin de hesaba katılması gerekir. Kuzey'in birkaç dönümlük vadi arazisi, çıplak ve aşınmış dağ yamaçlarındaki geniş toprak sahalarından çok daha değerli idi. Çin toplumu, askerî komutanların anarșisi, iç savas ve Japon saldırısı yüzünden buhrana sürüklendikçe, kiracılık da muhtemelen artmıștır. Nitekim, 1949. 1952 toprak reformu sirasinda toplam nüfusun $\% 10^{\prime}$ undan azım oluşturan toprak ağaları ile varlıklı köylülerin, arazinin \% 70'ine sahip oldukları ortaya çıkmıștı. Öte yandan, işlenen arazilerde aşırı bir parçalanma vardı. Tek bir ailenin işlediği birkaç dönüm. lük toprak, çok sayıda dağımık parçalara ayrılmıștı. Bu durum, münferit çiftçi farklı türde topraklara sahip olabildiģinden bazı hallerde iş̧e yaramaktaysa da, toplum yönünden büyük bir kayıptı.

Çin köylülerinin büyük çoğunluğunun içinde yaşadığı yoksulluk çeșitli belgelerle yansıtıldığından, burada üzerinde durulması gerekli değildir. ${ }^{3}$ Yine de, komünistlerin karșılaştıkları ekonomik problemlerin niteliğini göstermek üzere bazı şeyler söylenmelidir. Münferit bir yoksul köylï fazla çalışma, ortanın üzerinde maharet ve iyi şansla varlıklı köylü durumuna gelmeyi başarabilirdi. Ne var ki, yoksul ve orta gelirli köylülerin büyük çoğunluğu için genel bir iyileşme ümidi yoktu. Toprak sahipleri, rant olarak genellikle mahsulün \% 50'sini alyyorlardı. Çoğunlukla aynı kișiler olan mukrizler ise $\% 40-\% 80$ kadar yllık faiz alırlardı. ("İyi» sayı. lan bir mukriz \% 25 talep ederdi.) Köylï, sermaye yokluğu yüzünden, mahsulünü biçer biçmez, fiyatlar düşükken satmak; tohum ile hayvan yemini ise fiyatlar yüksekken satınalmak zorundayd. Buna karşıltk toprak sahipleri, hububat spekülasyonu ya-

1 «Land and Labour in China» S. 64.

2 "Ten Great Years» s. 34 (Çinin resmî istatistik el kitabı).

${ }^{3}$ Bir köy halkının acı anıları için özellikle Bkz: Jan Myrdal "Report from a Chinese Village.» 
parak gelirlerini takviye edebilecek durumdaydı. Bu yüzden, köylü, sermaye biriktirme ve böylece toprağı iyileștirme, cahil olduğu için bildiği varsayllamıyacak olan daha iyi tarım yöntemlerini benimseme şansına sahip değildi. Nitekim, çoğu köylï sürekli olarak borç içindeydi; zaman geçtikçe daha da batıyordu. Köylïler, yalnız anaparayı değil, faizini bile ödeyemeyecek duruma gelerek, ellerindeki küçük toprağı da kaybetme tehlikesi altmda faizin faizini ödemeye zorlanıyorlard.

Toprak sahipleri, ödünç verenler ve tüccarların mallara zorla el koymaları dışında doğal afetler de vardı. Bunlar merkezî otoritenin çökmesi üzerine, sulama ve taşkınları denetleme sisteminin bozulmasıyla şiddetlendi. Köylü en az geçim haddine o denli yakın yaşamaktaydı ki, gelirinde küçük bir azalma onu bu slnırın altına itmeye yetiyordu. Dayanacağı yedeği de yoktu. Kıtlık, olağanüstü sayllmayan normal bir olaydı. Çin öylesi büyük bir ülkedir ki, çeşitli kesimlerinde sel ile kuraklığa aynı zamanda rastlanması olasıdır. Bu yüzden, hemen her yıl Çin'in her hangi bir kısmında insanlar açlıktan ölmek yada ağaç tekneler üzerinde canlarını kurtarmaya çabalamak durumundaydılar. Bazen, bes milyondan fazla insanın öldüğui 1929 yllndaki gibi, büyük afetler de ortaya çıkmıştır. Bütün bunlardan korunabilmek rasyonel bir dağıtım sistemini gerektirir. Oysa böylesi bir sistem mevcut değildi.

Günlük mamul ev eşyaları 1949'dan önce hâlâ geleneksel yöntemlerle evlerde yada küçük sanatkârlarca yapıllyordu. Aynı husus, daha düşük oranda olsa da, varlıklılarca alınan lüks maddeler için de doğruydu. Özellikle kıyı bölgelerdeki bazı küçük sanatlar ucuz Batı mallarının rekabetiyle karșı karșıyaydı. Batı girișimlerinden uzak olan iç kısımlarda ise küçük sanatkârlar işlerini yürütebildiler. Büyük bölümü 1900 'lerden sonra kurulan modern imalât endüstrisinin önemli kısmı Şenyang (Makden), Harbin, Tiençin ve hepsinden çok Şanghay gibi birkaç buiyük șehirde görülüyordu. Bunlar, yabancıların özel ayrıcalıklar elde etmeyi başardıkları bölgelerdi. Uretilenler ise, daha çok tekstil ve sigara gibi basit mamullerdi. Bunun yanısıra, ağır endüstrinin başlangıcı da mevcuttu. Çelik Mançurya'da Japonların denetimi altında ve Sanghay'da üretiliyordu. Ancak, 1949 öncesi maksimum üretim hacmi bir milyon tondan azdı. Makine yapımı endüstrisi hemen hiç mevcut değildi. Çin, modern donatım mallarını ithal etmek zorundaydı. Madencilikte bir ilerleme olmuşsa da, Çin doğal kay. naklar yönünden zengin bir ülke sanılmıyordu. Büyük şehirlerin 
ihtiyacını karşılamak üzere birkaç enerji istasyonu kurulmuştu. Ancak, kırsal bölgelerde elektrik bilinmiyordu. Çin'in geniş hidroelektrik potansiyeli de el değmeden bırakılmıştı. Ulaştırma sistemi ilkel ve yetersizdi. Ülkenin geniş sahalarına motorlu araçlarla girilemezdi. Çoğunluğu Mançurya'da ve Doğu'nun sahil șehirlerini birbirine bağlayan biçimde olmak üzere yalnız $12.000 \mathrm{mil}$ uzunluğunda demiryolu vardı. Bu arada, 1949 Çin'indeki endüstri temeli ile altyapı kuruluşlarının 1914'den önce Sovyet Rusya, hatta bağımsızlığından önce Hindistan'ın sahip olduğundan daha küçük çapta bulunduğuna işaret etmek yerinde olur.

Çin, 1949 'da, işte böylesi yoksul ve geri bir ülke idi. Kaldı ki, on yillarca süren savaş ekonomik sistemini de çökertmişti. Olan endüstrinin büyük bölümü yıkılmış, tarımsal üretim son derece azalmış ve ulaştırma sistemi ciddi şekilde bozulmuştu. Bütün bunlar, Çan Kay \$̦ek'in Komintang savaş çabalarının akçasımı sağlamak üzere para matbaasına başvurmasıyla birlikte, dörtnala enflasyon ve para sisteminin çökmesi sonucunu doğurmuştur.

\section{KALKINMANIN PROBLEMLERİ}

Çinli komünist liderler, 1949 'da başa geldiklerinde, bu ülkeyi mümkün olan en kısa zamanda güçlü, müreffeh bir modern devlet durumuna sokmayı, başhıca amaçları olarak bildirdiler. Çin gibi geniş bir ülke için bunun tek çıkar yolu endüstrileşmekti. Endüstrileşme ise önce istihdamın yapısında tarım dışına kaymayı gerektirirdi. Nüfusun artan bir bölümü tarım-dışı işlerde çalıştrrllacaktı. Ancak, bu insanlarm beslenmesi gerekiyordu. Bu yüzden tarımı geliştirerek çiftlikte kişi başına verimliliği artırmalıy. dı. Kaldı ki, Çin'de tarım birçok endüstri kolu için pamuk ve tütün gibi ilkel maddeleri yaratmaktaydı. Söz konusu endüstri kolları, şüphesiz, ilkel maddeler arzında artış olmaksızın genişleyemezdi. Üstelik, mamul malların önemi giderek artmakla beraber, az gelișmiş bir ülkenin ihraç mallarının çoğu, Çin'de olduğu üzere, ilkel maddeler yada tarımsal ürünlerdir.

Çin ihtiyaç duymakla beraber ya halen hiç yapamadığı yada çok yüksek maliyetle yapabileceği ileri teknoloji donatımın artan miktarlarda ithal edebilme imkânın kazanacaksa, ihracatını genişletmelidir. Nihayet, nüfusun büyük çoğunluğu tarımda çalıștığından, tarımsal çıktının artırılması, bu çoğunluğun hayat standardını yükseltmek demek olur. Endüstrileşme yalnız fabrikalarun kurulması değildir. Tarım da endüstrileştirilmelidir. 
Endüstri ile tarım, bu şekilde, birbirine bağlıdır; birinin gelişme hızı diggerini de etkiler. Bu yüzden, tarımsal gerilik, Çin'de, diğer az gelişmiş ülkelerde olduğu gibi, endüstriyel geliş̧menin başhca engelidir. Ancak, Çinlilerin bu ve diğer problemlerle nasıl başa çıktığımı görmeden önce, Çin'in kendisine özgü ve aksatıcı iki güclü̆ğunü temsil ettiği düşünülen etkenler üzerinde duralım. Bunların ilki kömür, demir madeni, petrol vd. gibi endüstrileşmenin temeli olan doğal kaynakların durumu; ikincisi ise nüfustur.

İlk güçlük hemen geçilebilir. Çin, doğal kaynaklar yönünden son derece fakir olsaydı bile, bu, kalkınmada karșı konulamaz bir engel teşkil etmezdi. Zira, bir ülkenin bizzat üretemediklerini ithal etmesi daima mümkündür. Japonya ve Ingiltere doğal kaynaklar bakımından fakir oldukları halde bașarıyla endüstrileşmiş iki örnek ülkedir. Çin'in durumuna gelince, temel maddeler için kendisiyle dost olmayan ülkelere bağlı bulunduğunda engel, ekonomik olmaktan çok siyasaldır. Ne var ki Çin, hepsiyle değilse de önemli ilkel maddelerin ekserisi ile çok iyi biçimde donatılıış görünmektedir. Böyle olmadığı yolundaki inanç, yetersiz araștırmalara dayanır. Çinin kömür rezervleri, dünyada en geniş olanlardandır; demir madeni de oldukça çoktur. Tungsten, kalay ve molibden gibi demirli-olmayan metallerde ise dünyada öncü durumdadir. Yeter bollukta bulunamayacak önemli kaynaklar, yalnız bakır ve petroldür. Yine de, son yillarda, özellikle Ta Çing'de, Çin'i bugünkï tüketim seviyesinde kendi kendine yeterli duruma sokan büyük kazılar yapılmıştır. Şüphesiz, talep arttıkça, bu durumun sürdürüleceği fazla olası değildir.

Bugünlerde, dünya nüfus patlaması hakkında çok șey yazılmıștır. Bu arada, Çin bakımından sorunun özellikle vahim olduğu sıkça ileri sürülmektedir. En kaba biçimiyle ortaya konan fikir, Çinlilerin sinsice yaklaşan açlığa maruz bulunmalarıdır. Yıldan yıla amansızca artan geniş niufus kıt kaynaklar ve özellikle toprak üzerinde baskı yaratmaktadır. Bunlardan çıarılan sonuç, Çin'in ileri bir tarihte tam bir çöküntüyle karşılaşacağı, aç kalabalıkların muhtemelen güneye, Güneydoğu Asya'nın zengin pirinç ülkelerine, yada kuzeye, Sibirya'nın el değmemiş topraklarına yayılmaya çalışacaklarıdır.

Önce tahmin edilen bu ekonomik olayların, böylesi bir siyasal geliş̧meye yol açıp açmayacă̆g sorulabilir. Bu bir yana, iddianın gerçek kaynaklarını tahkik etmek, amacımız yönünden daha önemlidir. Hali hazır Çin nüfusu yalnız Pekin'deki yetkililerce bilinmektedir. Yine de, mevcut verilere dayanarak bir tahmin yapa- 
biliriz. Ilk elverişli nüfus sayımı 1953'de yapılmıș, kıta Çin'in nüfusu 582,6 milyon olarak bulummuştur. Bu rakam Çin dışında, genellikle doğru kabul edilmektedir.

Dünya nüfusu, halen, jnsanltk tarihinin her hangi başka bir dönemindekinden daha hizla artmaktadır. Ingiltere ve diğer ileri ülkelerde nüfus 19. asırda hızla çoğaldı. Ingiltere'de üç katını aştı. Ancak bu büyük artıș, Kuzey Amerika ile Avusturalya'da gıda üretimi için bol toprak mevcut olduğu ve hem endüstriyel hem tarımsal verimliliğin hızla yükseldiği sırada ortaya çıkmıștır. Günümüz az gelişmiş ülkelerj tamamen farklı bir durumla karşı karşıyadırlar. Nüfusları hızla arttığı halde, çoğu kez ekonomik gelişme geride kalmaktadır. Öte yandan, nüfusun baskısını azaltacak çapta büyük dış-göç ümitleri de yoktur. Nüfusun hizla artıșı, 19. asırdaki gibi, doğum oranlarındaki yükselmeden çok ölüm oranlarındaki düşme yüzündendir. Gerçekte, en bozuk ve güiçsüz hü. kümetler bile, küçük çaplı kamu sağlığı yatırımlarıyla, modern dünyadaki ölüm oranlarını düşürme iktidarında görünmektedirler. Hintli demograf S. Çandrasekkar, Çin'de 1952 yllnda \% 018 olan ölüm oranının 1957 de $\% 0$ 11'e düştüğünü tahmin etmiştir. Bu oranlar, 1964.1965 için Hindistan'da \% 0 21-23, Japonya'da $\% 07$ idi. Çindeki doğum oranı ise, \% 037 ile $\% 034$ arasında olmak üzere tahmin edilmiştir. Oran Asya'ya göre düşüktüur. (Hindistan'da \% 0 39-40, Endonezya'da \% 0 40-46). Bu rakamlar 1ş1ğında, Çin'deki tabiî doğum oranının \% 2 ile \% 2,5 arasında bulunması olasıdır. Çu En-Lay, 1960 yllında Edgar Snow'a, maksimum artışın $\% 2,4$, ortalamanın ise $\% 2$ olduğunu bildirmiști. $\mathrm{Bu}$ oran, az gelişmiş bir ülke için, şüphesiz, olağanüstü yüksek değildir. Gerçekte Latin Amerika ile çoğu Asya iulkelerindekinden düşük olup, aşağı yukarı Hindistan seviyesindedir. Eğer Çin nüfusu 1953 'den beri $\% 2$ hızla artsaydı, bu yl 790 milyona ulaşacaktı. Ne var ki, Çin dışındaki hiç kimse, oranın son yıllarda ne olduğunu bilemez ve nüfusun yukarıda belirtilenden az olması da pekalâ mümkündür. Çinliler 700 milyondan söz etmeye devam ediyorlar. Bu, șüphesiz, genellikle kullanılan yuvarlak bir rakamdır. $\mathrm{Bu}$ rakamın gerçeğe 800 milyondan daha yakın olabileceği ihtimali yine de yabana atılamaz. \% 2 oranı doğru olsaydı, Çin her ekili hektar bașina Hindistan'in iki katı, Japonya ve Ingiltere'nin ise yarısı kadar insana sahip bulunacaktı.

Nüfus bu hızla sürekli artarsa, sonunda dayanılmaz bir durum dogacaktır. Ne var ki, hali hazır trendleri basitçe geleceğe uzatamayız, Once, doğum oranının Çín'de ve Ưưüncü Dünya ülke- 
lerinde neden bu kadar yüksek olduğunu araştırmalıyız. İnsanların geniş aileye sahip olma arzularının, șüphesiz birçok kültürel ve dini nedenleri varsa da, salt ekonomik olanları da vardır. Ça. lışamıyacak kadar ihtiyarladıklarında, eğer devlet yaşılıtk maaşı bağlamazsa, aileleri dışında bu insanlara kim bakacaktır? Ailesiz bir adam, hayli belirsiz olan dünyamızda güvenlikten yoksundur. Bu nedenle, çocuklar gençliklerinde ekonomik bir yük olsalar da, büyüdüklerinde dikkate değer kiymetlerdir. Hele, pek çoğunun olgunlaşmadan ölmesi muhtemel oldưundan, başlangıçta fazla sayıda çocuğa sahip olmak gerekmektedir. Devlet ihtiyarlar, hasta ve bahtsızlar için ekonomik güvenlik sağlamadığında geniş aileye sahip olmak cehalet değil, akıllıca kendi çıkarını gözetmektir. Bununla birlikte, koșullar deģişip kişinin yalnız ailesine dayanmak zorunda kalmaması, öncekinden daha fazla çocuğun olgunluk çağına kadar yaşayabilmesi durumunda da kökleşmiş törelerin günden geceye kaybolması beklenmemelidir. Ölüm oranları düsserken, doğum oranlarının yüksek kaldığı bir geçiş dönemi olacaktır. Sonunda, doğum oranlarının da yeni koşullara uyarlanarak düşmesi beklenebilir. Bu süreç, kadınların statülerindeki değişmeler ve bunlar için iş olanaklarının artması gibi etkenlerle hızlandırılabilir. Bütün bu lehte koşullar, bugün Çin'de vardır. Ancak, geçiş dö. neminin ne denli uzun olacağ 1 sorusu yine ortada kalmaktadır.

Söz konusu sürecin süresi kesinlikle tahmin edilemezse de hükuimet bunu hızlandırmaya çalışmaktadır. Doğum kontrolï teşvik ediliyor. Lehte ileri sürülen nedenler, bir bütün olarak nüfusun frenlenmesinden çok genellikle kadinların refahı olmakla beraber, doğum kontrolü teșvik edilmektedir. Gebeliği önleyici araçlar, ucuz fiyatlarla ülkenin her yanında bulunabilir. Doğum oranını yüksek kalmaya yönelten bir diğer etken, toplam nüfus içinde gençlerin ağır basmasıdır. 1953 sayımı nüfusun \% 36'sının 15 yaşından küçük olduğunu ortaya koymuştur. Buna karşılık, aymı oran Ingiltere'de 1966 yll için \% 23'dür. Yine de Çin'in durumu, diğer bazı Asya ülkeleri kadar vahim değildir. Örneğin, Filipinler' de 15 yaşından küçük çocuklar, nüfusun \% 46 kadarını oluşturmaktadır. Çin yetkilileri, yine de geç evlenmeleri teşvik etmektedirler. Erkekler 25, kızlar 21 yaşından önce evlenmemeye zorlamyor. Ailenin genişliği gibi kişisel bir konuda, önceleri denenmişse de, büyük kampanyalarm fazla etkili olması beklenemez. Mamafih, doğum kontrolï lehindeki propaganda halen daha az önemde olmakla beraber yine de yaygind $\mathrm{r}$. 
Bütün bunlara göre, nüfus problemi ne denli ciddidir? Ișlenerek ekilmeyi bekleyen geniş ve verimli araziler olsayd, Çin'in gerçekte olduğundan daha iyi duruma geleceğini kimse yadsımayacaktı. Çin, gördüğümüz gibi, nüfus yönünden diğer Asya ülkelerinden daha kötü durumda olmayıp, bazı bakımlardan daha da iyi durumdadır. Eğer tarımsal üretimi artırma olanağı bulunmasaydı, durum gerçekten çetin olurdu. Ne var ki, ileride iddia edileceği üzere, tarımsal iyileştirme potansiyeli, halen büyük çabalar gösterilmişse de, hi̧̧ bir yerde tüketilmiş değildir. Bu yüzden, nüfusu daha düşük hızla artsaydı, Çin'in işi daha kolaylaşacaktıysa da mevcut artıș hızı kalkınma yolunda yenilmez bir engel değildir.

\section{4. ÇİN EKONOMIK GELIȘME SEXRÍNİN ANAHATLARI}

Çin ekonomi siyasasını ayrıntılarıyla incelemeye girişmeden önce olayların kısa bir panoramasinı vermek yararlı olacaktır. Çin'in günümüze kadarki ekonomik gelişmesi beș așamaya ayrılabilir :

a) 1949-1952 : Milli Ekonominin Onarrlma Dönemi

Barışçı duruma dönülmesiyle-hiç olmazsa Çin'in kendi içinde, dıșta ise Kore Savași sürmekteydi- ekonomik canlanma bekleniyordu ki, bu gerçekten oldu. 1952 yllma kadar ekonominin bütün sektörleri, 1949 öncesi en yüksek üretim seviyelerine ulaştı; bazı sektörlerde bu seviye de aşıldı. Bu dönem içinde, tarihin baş̧ıca toplumsal dönüşüumlerinden biri ortaya çıktı: Toprak ağaları ve zengin köylülerin arazilerini yeniden dağıtan toprak reformu. Buna karşllık, ne tarım ne de endüstride geniş çapta devletleştirmeye gidilmedi. Hükümetin hoşgördü̈̈̈̈ millî kapitalistlere karșlhk bürokrat kapitalistler olarak belirlenen Komintang taraftarlarlnın ellerindeki endüstriyel kiymetler bunun istisnasidır. Yine de, özel endüstriyi kamu sektörüne katma çabası bașlamıștt. Hükümetin önemli bir başarısı, orta sınıfın desteğini kaybettirerek Çan Kay-Şek'in yenilmesinde bașlıca neden olduğu anlașlan enflasyonu önlemektir. Bu, kısmen piyasaya arz edilen mal miktarını artırmak ve ulaştırma sisteminin eski hale getirilmesi ile devlet ticaret şirketleri kurularak istifciliğin önlenmesi; kısmen de bütçenin denkleştirilmesi yoluyla sağlanan ve bir Çin hükümeti için rastlanılmamıs bir başarıdır. 
b) 1953 - 1957 : Beş Yıllık Plan Dönemi ve Endüstri ile Tarmmun Sosyalizme Dönï̧̧̧їmü

Geniş kapsamlı planlama bu dönemde başladı ve etkisi, özel sektör payının azalması ölçüsünde fazlalaştı. Ticaret ve endüstride, kamu sektörü, daha başlangıçta egemen durumdaydt. Ancak, aşağıda açıklanacağı üzere, kapitalist endüstri fiilen ortadan kalkıncaya dek kapitalistler, gelişmelerini sürdürdüler. Tarımda kooperatifleşme hareketi, özellikle 1955-1956 yıllarında kökleşme yolunu tuttu. 1956 yll bitmeden, hemen bütün köylüler kooperatifler halinde örgütlendiler ve özel toprak sahipliği geniş ölçüde azaltıldı. Beş Yıllık Plan'da çok ileri amaçlar saptanmışsa da, hemen hepsinin gerçekleştirilmesi, hatta bir kısmının aşıIması, bunların aşırı amaçlar olmadığını gösterdi. Gerçekte, ekonomi çok yüksek bir hızla kalkınmıștı.

\section{c) 1958 : Büyük İleri Hamles}

Plan hedefleri sürekli olarak ileri götürüldüğü ve çıktı hacmini artırmak üzere benzeri görülmemiş çabalara girişildiğinden, bu yll, öncekilerden daha yüksek bir genişleme hızına tank olmuştur. Ne var $k \hat{k}$, istatistikler bu dönemde kesilmeye başladığından, gelişmenin büyüklü̈g̈̈ tartışma konusudur. Söz konusu yllın sonunda, kırsal bölgelerde ekonomik örgütlenmenin ilk birimi olarak halk komünlerinin kurulması, tarımda sosyalizme geçilmesinde yeni bir aşamayı gösterir.

\section{d) $1959 \cdot 1961$ : Buhran Yillarn}

Doğal afetler ve komünlerdeki örgütlenme problemleri, gelişme hızını yavaşlattı. Ağır endüstriye öncelik verme siyasası tersine çevrilerek "tarımm ekonominin temeli, endüstrinin ise öncü sektör» olduğu yolundaki slogan benimsendi. 1960 yllinda Sovyet ekonomik yardımının kesilmesi, yeni bir güçlük doğurdu. Kaynaklar tekrar glda üretimine yöneltildi. Buna rağmen, șiddetli bir kıtlık vardı. Ancak, tayınlama ve ortak çabalarla açlık önlenmiş. tir.

${ }^{4} \mathrm{Bu}$ dönem, Çinlilere göre 1960'a kadar sürer. Bazı yönlerden hâlâ devam ettił kabul edilir. Ancak, 1959 ve 1960 ylllarında önemli siyasa değişiklik. leri yapıldı̆̆ından, genel eğilime uyarak, terimi yalnız 1958 yilını göstermek tizere kullaniyoruz. 


\section{e) 1962 -1968: Íyileşme Dönemi}

1962 y1lında tarımsal hasıla yeniden yükseldi ve o zamana dek olmayan iyi hasatlar yapıldı. Tarımsal buhranın sona ermesi üzerine, endüstri, gelişmeye devam etti. Genel istatistiklerin yokluğu yüzünden, bu dönemdeki gelişmenin ölçeği hakkında fikir yürütmek güçtür. 1966'da bașlayan Kültür Devrimi'nin ekonomi siyasasında önemli değișiklikler yaratmış olması mümkündür. Așağıdaki iktibastan da anlaşılacă̆ı gibi, Büyük İleri Hamle sırasındaki bazıı siyasalara dönülmüş bulunması olasıdır :

«Devrime sarılmal, üretim ve diğer işleri ileri götürmeli, savaşa karșı hazırlıklı olmalı; sosyalist endüstri, sosyalist tarım ve ülkemizdeki diğer bütün sosyalist kurumlarnn kurulması yolunda daha da iyi çalışmalıyız. Büyük proloter kültür devrimi, sosyalist üretimin geliștirilmesi yolunda muazzam bir itici güçtür. Devrim sosyalist yapımızdaki yeni hamleyi ileri götürmektedir ve böyle yapmaya devam edecektir de.» *

\section{5. ÇIN EKONOMİ SIYYASASI}

\section{a) Tarm}

\section{Kurumsal Reformlar}

Hükümetin tarım konusundaki nihaî amacı, daha başlangıçta, tarımın bütïnüyle sosyalizasyonu olarak belirtilmişti. Toprak ve diğer üretim araçlarında özel mülkiyetin kaldırlarak yerine bütün halkın ortak mülkiyeti konulacaktı. Ne var ki, bu hedef şimdiye dek yalnız toprăgı devlete ait olan ve ücretli işçilerle ekilen devlet çiftliklerinde gerçekleştirilebilmiştir. $\mathrm{Bu}$ çiftlikler ise toplam arazinin küiçük bir bölïmünü teşkil eder. Hâlâ tamamlanamıyan sosyalizasyon sürecinin ilk adımı, feodalizmin yıkılmasıyd. $\mathrm{Bu}$, iç savaşın sonuçlanmasından önce kurtarılan böIgelerde daha önce yapılmakla beraber, genellikle 1949-52 döneminde bașarılmıștır. Yeniden dağıtımdan, 300 milyonu aşkın köylü yararland. Toprak ağalarının yalnız arazilerine değil tarım araçları, yük hayvanları ve diğer varlıklarma da el konulmuștur. Yine de toprak ağaları tamamen yoksul bırakılmayıp, kendilerini geçindirmeye yetecek kadar araziyi alıkoymalarına izin verilmiștir. Köylülerin sırtındaki toprak kirası ve faiz yükü, bir hamlede fii-

\footnotetext{
* Çin Komünist Partisi, 8. Merkezî Komitesinin genişletilmiş 12: tam üyeli toplantısınun tebliği. 1 Ekim 1968.
} 
len kaldırılmıştır. Böylece Çin kendi toprağını işleyen küçük tarımcilar ülkesi durumuna geldi. Yalnız, toprak reformu köylüler arasındaki bütün gelir farklarını kaldırmadı. Zengin köylülere daha 1lımlı davranıldı; orta gelirli köylüler ise dağıtımdan pay aldılar. Böylece, reformdan sonra, orta gelírlilerin sayıca artmasına rağmen varlıklı ve yoksul köylüler de bulunmaktaydı.

Toprak reformu, başlangıçta karşı konulmaz bir siyasal talebe cevaben yapılmıștır. Ancak, komünistlerin reformun üretim üzerindeki olası etkilerini de hesaba katmış olmaları gerekir. Gerçekte, komünistler toprak ağalarının tamamen asalak sayılabilecegi; ortadan kaldırılmaları halinde, üretimin zarar görmeyeceği sonucuna vardılar. Bu düşünceleri, endüstriyel kapitalistlere karşı tutumlarıyla tam bir zitlık içindedir. Böylesi bir reformun bazı ülkelerde, hiç olmazsa piyasa için yapılan üretimde büyük azalmalara yol açması olasıdır. Örneğin, 19. asır İngiltere' sinde, toprak ağaları tarım işçilerine özellikle cömert davranmıyorlard. İş̧̧iler, arazi lehlerine olarak yeniden dağıtıldığında daha iyi duruma gelebilirlerdi. Ama toplam çıktını azalması olasıd. Zira, Ingiliz toprak ağaları arazilerini iyileștirme çabasındaydılar ve toprağa yatırım yapıyorlardı. Bu kişiler, işç̧lerin yoksun olduğu sermaye, ticarî maharet ve teknik ustalığa sahiptiler. Ne var ki, tarımsal çıktı rakamlarından anlaşlabileceği gibi, Çin'dekj durum böyle değildi. 1949 yılı için hububat çıktısı 113 milyon ton olarak tahmin edilmiştir. Bu rakam, 1952 yll için 164 milyon tondur. ${ }^{5} \mathrm{Bu}$ iyileșme, şüphesiz ki, geniş ölçüde barış koșullarının yeniden sağlanması nedenine dayanmaktaysa da, reformun yaratt1ğ büyük değișmenin, söz konusu iyileșmeyi engellemediği açıktır.

Öte yandan, köylülerin, ekonomide, refahlarmın artışı ölçüsünde önemli rol oynayacakları kabul edilmiștir. Toprak reformu, fakir köylülerin lehine sürdürülerek daha eşitleyici biçimde yapılabilirdi. Ancak, böyle yapılması orta gelirli köylüleri soğutabilir ve üretimde aksama yaratabilirdi.

Feodal toprak ağalığ1 yerine küçük köylüyü getiren toprak reformu, tarımsal geriliğin her hangi bir problemini çözemezdi. Çin hükümeti için şimdi olduğu gibi o zaman da başlıca iki olanak vardı. Bunlar, Çin'de kapitalist yolu izleme ve sosyalist yolu izleme olarak betimlenmiștir. 1952'lerde kapitalist yola yönelme, varlkklı bir köylü ekonomisinin gelişmesini teșvik etme șeklinde

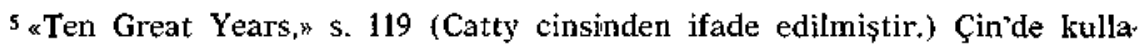
nlan bir ağırlık ölçuisui olan Catty, 1,3 libre'ye eşittir. (Ç. N.) 
ifade edilmiştir. Daha gayretli ve ticarî bakımdan daha açıgöz çiftçiler, daha az gayretli yada şansızların toprakların ele geçire. rek onları işçi olarak çalıştıracaklardı. Hükümet bir yandan başarılı çiftçiye yardım edip ödüllendirirken, toprak ağalğının yeniden gelişmesini denetleyecekti. Yani, hükümet, Batı'da az gelis. miş ülkelere sıkça salık verilen, Batı ülkelerinin bir zamanlar bizzat uyguladıkları, köylü tarımından geniş ölçekli kapitalist tarımı oluşturucu bir siyasayı izlemiş olabilirlerdi. Şüphesiz, böyle yapıl. ması, çıtı hacminin artması gibi bazı sonuçlar yaratabilirdi. Ne var ki, söz konusu dönüșüm, Batı'da bile asırlar içinde gerçekleşmiștir. Salt ekonomik sakıncaları bir yana, böylesi bir tutum, Çin'de siyasal bakımdan bütünüyle kabul edilemez durumdaydı. Zira, bu siyasanın benimsenmesi, kırsal bölgelerdeki eşitsizliği şiddetlendirme ve azınlık yavaş yavaş sermaye biriktirirken çoğunluk için acı koşulların sürmesine göz yumma anlamına gelecekti. Bu ise, devrimin başlıca amaçnı yadsımak olurdu.

Ancak, tamamen sosyalize edilmiş tarımın nesnel koşulları şimđiye dek var olmadı. Sosyalizasyon, ileri derecede makineleşme, bilimsel yöntemler ile maharetli ve eğitilmiş işgücünü gerektirir. Bunlar, mucizevî şekilde, temin edilseydi bile, tarımla uğrașan kütleler henüz benimsemeye hazır olmadıklarından sosyalizme hemen geçilmesi olanaksızd. Çinlilere göre, siyasal bilinçlenme henüz yeterli yoğunlukta değildi. Bu yüzden, tedricî bir siyasa benimsendi. Köylüler, 1958 'de komünlerle en yüksek derecesine varan, gittikçe daha büyük birlikler kurmaya teşvik edildiler.

Toprak reformu sırasında atılan ilk adım, karşılıklı yardım takımlarının oluşturulmasıdır. Takımlar, genellikle birbirinin toprağını miiștereken ya yalnız ișlerin yoğunlaștığı mevsimlerde yada sürekli olarak işlemek üzere anlaşmış on kadar aileden meydana geliyordu. Sonraki adım, alt-kooperatif (lower cooperative) denilen kuruluşlardır. Köylüler toprak, araç ve işgüçlerini bu kooperatiflerde biraraya getiriyorlardı. Fakat, dilediklerinde bunları geri alma olanağ̀ da tanınmıștı. tlk zamanlarda, çoğu köylü bu yolu denedi. Kooperatif üyelerinin toplanan geliri iki bölümdú. İlk bölüm, işgücii hizmetleri için, çalı̧ma puanları yöntemine dayanan ödeme idi. Her özel iş cinsi, belirli sayıda çalıșma puan ile değerlendiriliyor; üyelere, yaptıkları işe uygun puanlar kaydediliyordu. Yil sonunda, bir çalışma puanının değeri alınan ürüne göre hesaplanır ve üyelere buna göre ödeme yapılırdı. İşgücü hizmeti için yapılanın yanısıra, kooperatife verilen mallar için de ödeme vardı. Fazla mal verenler, fazla alırlardı. Bir alt-kooperatif, çoğunlukla 
20-40 aile içerirdi. 100 ilâ 300 aileden oluşan üst-kooperatifler (higher cooperative), alt-kooperatiflerin birleșmesinden meydana gelirdi. Bu ikisi arasındaki başlıca fark, üst-kooperatiflerde yalnız harcanan işgücủ karșılığı ödeme yapılıp, konulan mal için bir şey verilmemesidir. Yine de kooperatifçe el konulan hayvanların sahiplerine ödünleyici bir ödeme yapılırdı. 1956 sonundan önce, köylü ailelerinin \% 96'si alt, \% 88'i de üst-kooperatiflere üyeydi. ${ }^{6}$ Genellikle bütün bir köyü içine alan üst-kooperatifler, bu dönemde kirsal bölgelerin temel ekonomik üniteleriydi.

Çin'in her bölgesinin, üst makamlarca önceden hazırlanmıș olan böylesi bir şemaya muntazam bir dizi halinde uyduğu sanılmamalıdir. Kooperatifleşme hareketi yavaș ilerlemiş, ancak, Mao Çe-tung'un 1955'in ikinci yarısındaki müdahalesinden sonra hız kazanmıştır. Şu daima açıkça ortaya konulmuştur ki, kooperatiflerin bașarısı köylülerin bunların ișleyeceğine inandırılmalarına bağlıdır. Öte yandan, kooperatiflerin başarılı olması için, kırsal bölgelerdeki sınıf çatıșmasına başarıyla karșı konulması gereği de kabul edilmiştir. Problemin niteliği, Mao tarafından Temmuz 1955'te açıklığa kavușturulmuştur. «Kapitalizmin içinden gelen güçler, her yandan fişkıran yeni varlıklı köylüler ve böyle olmaya çabalayan orta halli köylülerle, son yıllarda kırsal bölgelerde sürekli olarak gelișmektedir. Öte yandan, birçok yoksul köylü yeterli üretim aracının bulunmaması yüzünden hâlâ yokluk içinde yaşamaktadır.» ${ }^{7}$ Maó, partinin hareketlerinde aşırı ihtiyatlı davrandığını, kütlelere öncülük etme yerine onların arkalarında kaldığını iddia etti. Taraftar olduğu siyasa, yoksul köylülere dayanmak ve onları orta gelirli köylülerle birleştirmekti. Yoksul köylüler, kü. çük arazi parçaları üzerindeki varlıklarının kararsızlığı ile yeterli araç ve hayvanları bulunmayışının bilincine vardıklarından, birleşmeye en çok hevesli olanlardı. Buna karşılık, orta gelirli köylüler, nüfusun büyükçe bir bölümünü oluşturuyordu. Bazıları, kendi kendine daha iyi is yapabileceğini düşüinür; güiçlerini yoksul köylülerle birleștirmekle onlarn seviyesine düșmekten çekinebilirdi. Bütün bunlara rağmen, parti, sonunda kooperatiflerin kırsal nüfusun çoğunluğunca şevkle benimsendiğini bildirdi. $\mathrm{Bu}$ iddia Batı'da, bazen șüpheyle karşılanmaktadır. Tarımsal çıtının dönem boyunca artması; Sovyetlerin kollektivizasyon çabaları sırasındaki gibi yaygın bir direniș olduğunun duyulmaması, köylüle-

6 Ibid. s 28

7 "On the Question of Agricultural Cooperation," 'Quotations from Chairman Mao Tse-tung' içinde. s. 33. 
rin uysallık ve tevekkülüne dayandırlmaktadır. Oysa, köyluiler devrim için verdikleri mücadele sırasında, uysal ve mütevekkil olmadıklarını gösterdiklerinden, yukarıdaki açıklama fazla akla yakın görünmemektedir. Büyük köylï çoğunluğunun, işbirliğinin daha iyi bir hayata götüreceğini farketmeye başlamış bulunması daha olasıdır. Çoğu köylü, toprağını Komünist Parti ve Kızıl Ordu vasıtasıyla elde etmiştir. Bu yüzden, toprakta özel mülkiyetten daha iyi örgütlenme yöntemleri bulunduğunu telkin ettiğinde, köylülerin partiyi dinlemesi beklenebilir.

Acaba, birleșmenin yararları nelerdi? Çinli liderler, daima, aşırı nüfuslarının bir sakınca değil, Çin'in başlıca kaynaklarından biri olduğunu iddia etmişlerdir. Yöneltilmeyi bekleyen çok geniş bir işgücü yedeği vardt. Bu, birçok șey ifade eder. İlkin, kütleler şevke getirilebilirse, çok daha sıkı ve iyi çalışacaklar; sonunda daha fazla yaratacaklardır. Mao'nun dediği gibi : «Kütleler, sinırsız yaratıcr güce sahiptir.» Bu, sorunun siyasal yönden görünümüdür. Ikinci olarak, eski toplumdaki bağımlılık durumları yüzünden, kadınların işgücü geniş ölçüde az kullanılmaktaydı. Kadınların hürriyete kavuşması, daima Çin Komünist Partisi programının bașlica maddelerinden biri olmuștur. Bu sorun, kadınlara eșit haklar tanıyan 1950 Evlenme Kanunu ile düzenlendi. Üçüncü olarak, az gelişmiş ülkelerde tarımsal istihdam, yapısı icabı, baskın şekilde mevsimliktir. Çin'de, hasat zamanlarında, halen de olduğu gibi, işgücü kıtlığıyla karşılaşılırdı. Y1lın dižer zamanlarında, özellikle ilkbahar ekimi ile sonbahar hasad arasındaki kış aylarında ise, tarımsal işgücü az çalıșmaktaydı. Kurtuluş savașı öncesinde, böyle olmast bir zorunluktu. Köylü, enerjisini korumak için oturarak vakit geçirmek ve olanak ölçüsünde az yemek zorundaydı.

Kooperatiflerin birinci yararı, bu fazla işgücünü harekete getirebilmeleridir. Daha önce de üzerinde durulduğu üzere, su arzinın denetlenmesi, Çin tarımının temelidir. Ne var ki, binlerce yıl. lik genişlemeye rağmen, tamamen sulanan kısım, toplam arazinin küçük bir bölümüydü. Su arzı, hele ülkenin Kuzey ve Kuzeybatı kesimlerinde genellikle yetersizdi. Sellerin denetlenmesi de ayn durumdaydı. Tam bir çözüme, ancak başlıca nehirlerin su verebilecek duruma getirilmesiyle ulaşılabilirdi. $\mathrm{Bu}$ iş halen geleceğe birakılmıștır. Baraj ve su depolarının yapılması geniş çaplı devlet çabasını gerektirir. Sarı nehir üzerindeki dev San Men projesi bı yolda bir örnektir. Yangçe nehri için de birtakım projeler yapılmıștır. Şimdilik hendek, havuz, sulama kanalları, küçük barajlar ve su depoları yapılarak, yine de köy çapında büyük işler başarı- 
labilir. Birinci Beş Yıllık Plan döneminde 13 milyon hekıardan fazla arazi, sulanan topraklara katılmıștur. ${ }^{8}$ Bunun hemen hemen yarısı, kooperatifleșme yönünde zorlamaların yapıldı̆̆ı 1955-56 kışında başarılmıştır. Böylece, sulanan arazi, toplamın üçte birine ulaşmıştır. 1957-58 kıșı ile Büyük Ileri Hamle sırasında, sulama oranını 1960'a kadar \% 60'a yükselten yeni gelişmeler oldu. Izleyen y1llarda da benzer gelişmeler ortaya çıkmıştır.

Kuzey'de, su kıtlı̆ı yanısıra ciddi bir erozyon da vardır. Bununla, tarlaları teraslama ve ağaç dikme yoluyla başa çıkılabilir. (Ikinci tedbir, Çin, kereste kaynakları bakımından nispeten fakir olduğundan, her durumda yararlıdır. Ormanlar, geçmiște genellikle kimseye ait olmadığmdan, yenilerini dikme zahmetine katlanmaksızın baltalanmıșlardır). Böylesi acil işler, daha varlıkh ülkelerde mekanik kürek, kazma makinası, damper kamyonları vd. gibi modern araçları kullanan, uzmanlaşmıs inşa ekiplerince yapılır. Çin'de ise, bu kaynaklar henïz mevcut değildir. Bu yüzden tek çare, ilkel araçlarla çalışan çok sayıda insanı kullanmak - işgücünü sermayeye çevirmektir.

Kooperatiflerin, ilkinin diğer bir cephesi olan yararı, üyelerinin tasarruflarmı hareketlendirebilmeleridir. Kooperatif, daha sonra komün, her yll, bütçesinin belirli bir bölümünü yaturım için ayırabilir. Ayrılan miktar, kendilerine bırakıldığında, münferit üyelerin yapacağı tasarruftan muhtemelen fazla olacaktrr. Bu, kısmen, köylünün küçük arazi parçası üzerinde pek az verimli yatırım imkânı bulabilmesi; kısmen de, daha büyük işletme birimlerinin, geride dayanacağı birşeyi bulunmayan münferit kișilerin muktedir olduğundan daha büyük risklere girişebilmesindendir. Büyük birimlerde risk dağıtılır ve üyeler bir proje başarısızlığa uğradığında yoksulluğa düssmezler. Üçüncü yarar, kooperatiflerin daha rasyonel tarım yöntemlerine fırsat vermeleridir. Küçük ve dağınık arazi parçalarının yol açtığı kayba daha önce değinilmişti. Bunları toplulaştırarak ekonomik büyüklüğe sahip tarlalar meydana getirilebilir, nerede ne yetistirileceği konusunda daha uygun kararlar alınabilir. Kooperatiflerin dördüncü yararı, bütünüyle aileye dayanı yerine bir sosyal güvenlik sistemi kurulması imkânı yaratmalarıdır. Zira, kooperatiflerin, ihtiyaç duyanlara ödeme yapabilecekleri bir refah fonları vardır.

8 "Ten Great Years," s. 130.

${ }^{9}$ Hughes and Luard, "The Economic Development of Communist China 1949-1960," s. 174. 
Kooperatiflerin yararları bunlardır. Potansiyel sakıncaları ise iki tanedir. Bunların ilki, kendi toprağında çalı̧̧an köylünün gerekli bütün hesapları kafasında yapabilmesine karșllık, daha geniş işletmelerde yönetim ve muhasebe ihtiyacının doğmasıdır. Çin gibi çoğunluğun cahil olduğu yerlerde başlangıçta güçlükler ortaya çıkar. Maliyet ve hasılat yanlış tahmin edilerek kayıp doğuran hatalar yapılabilir. Çin'in bugünkü genç kuşağı okuryazardır. Şimdiye dek öncülü̆g̈i üstlenmiş olan eski kuşak ise genellikle böyle değildir. Ancak, bu sorun, daha yaygın eğitimle, zaman içinde çözümlenecektir. Ikinci sakmnca, insanların kendileri için çalış̧ak yerine daha geniş birimler için çalışmaya bașlamalarının, müşev. viklerinin kaybı yüzünden gayretlerinin azalmasına yol açmasıdır. Müssevvikler konusu üzerinde, ileride daha fazla durulacaktır. Șimdilik, Çinlilerin maddî müşsevviklerin gerekliliğini daima kabul ettiklerine işaret etmekle yetinilebilir. Çinliler, ihtiyaca göre ödeme yolundaki komünist ilkeden çok, işe göre ödeme şeklindeki sosyalist ilkeye sadık kalmışlardır. Çalışma puanları sistemi bunun kanitıdır. Daha fazla çalışanlara, daha güç ve zahmetli is yapanlara daha çok ödenir.

Gerçekte, kooperatifler uzun süre devam etmediler. 1958'in bitiminden önce hemen bütün kooperatifler, bütünleşme yoluyla, daha büyük birimler olan komünleri meydana getirdiler. Ancak, kooperatifler için söylenenler, aynen yada daha güçlü olarak komünler hakkında da söylenebilir. Bununla birlikte, komünler yalnız basit üretim birimleri değil, yönetim birimleriydiler de. «Hsiang” denilen mahallî idare kendileriyle birleștiğinden, komünler yalnız tarımdan değil eğitim, sağlık ve savunmadan da sorumluydular. 1959 mart'inda ortalama 5.000 üye aileye sahip $26.000 \mathrm{ko}-$ mün vard..$^{10}$ Bunların hepsi değilse de bazıları, çok ileri siyasalar benimsemişlerdir. Kooperatife katılan köylülerin arazilerinin küçük bir bölümünü, kendileri yada serbest piyasa için üretim yapmak üzere muhafaza etmelerine izin verilmiştir. Bazı hallerde bu imkan kaldırılmış; özel topraklar ortak topraklara katılmıştır. Yine de bazı hallerde serbest arz sistemi konulmuştur. Üyelere, yaptıkları işe bakılmaksızın gida tayini ve bazen de, diğer temel ih. tiyaçları verilirdi. Komünlerde giyecek, çanak-çömlek ve kağı̆t yapan küçük teşebbüsler kuruldu. Bunların üzerinde, "arka-avlu çelik fırınları» denilen kaba yerli yöntemlerle, kırsal bölgelerde çe. lik üretilmesi yönünde ülke çapındaki kampanya vardı.

${ }^{10}$ Hughes and Luard, age, s. 116. 
Çin Komünist Partisi Kongresi 1958 sonunda toplandığnnda bu uygulamalarm bazılarmı ihtiyatla onayladı. Kongre, mahsulün gerçektekinden daha fazla olduğu varsayımına göre hareket ediyordu. (Heyacanla șişirilen ilk raporlar, mahsulün 1957'dekinin iki kat1 olduğunu iddia ediyordu). Bu yüzden, gida bolluguna henüz erişilmediği kabul edilmekle beraber, kararlar, tarım alanında bir çeşit günes doğmuşcasına alınıyordu. Komün üyelerinin ev, araç gibi özel mallarına saygı duyulacağı; domuz ve kümes hayvanları besleme cinsinden özel ek çalıșmalarm serbest olacağı ifade edildi. Komün üyelerinin gelirlerinin büyük bölümünün esas çalışmalarından gelmesi șartıyla, serbest arz sistemi destekleniyordu. Hububat üretimine ayrilan arazi, entansif tarım yoluyla küçük bir toprak parçası üzerinden daha yüksek verim elde edilerek azaltılacak; kalan kısım, diğer amaçlar için kullanılacaktı.

Durum değiştikçe bu siyasa da değiștirilmeliydi. 1958, bașlan. gıçta düşünüldüigü kadar olmasa da, şüphesiz iyi bir mahsul yılıydı. Izleyen yıllar ise son derece kötü olmuștur. 1959-1960 ve 1961 yıllarında, eși görülmedik çaptaki doğal afetler, ülkeyi tahrip etti. 1959 'da, ekilen arazinin üçte birini oluşturan 440 milyon dönümlük arazi sel yada kuraklıktan zarar gördü. 1960 yılında ise kuraklık, siddetli kasırga, su baskınları ve diğer afetler ekili arazinin yarısını aşan 660 milyon dönümlük toprağı etkiledi; ciddî şekilde tahrip olan 220-260 milyon dönümlük kısımdan ise yer yer hiç mahsul alınamadı. Öte yandan, Şantung'da Sarı nehrin bir ay kadar kuruması, hemeu hiç duyulmadık bir olaydır." Bu koşullar altında, uzun dönernli siyasa çerçevesinde düşünmek dışında, ekili araziyi daraltmak söz konusu olamazdı. Serbest arz sistemi için de aynı durum vardı. Tarımsal çrktı azalmıştı. Artırılması, hiç değilse, eldeki tüm olanaklarla, daha da düşmesine engel olunması gereki. yordu. Ciddî bir gıda sıkıntısı doğmuștu. Çin, sosyalist ülkelere birtakım gıda maddeleri ihracını ertelemek ve dışarıdan buğgday ithaline bașlamak zorunda kaldı.

Bu dönemde genel siyasada yapılan büyük değişiklikler, ileride, daha ayrıntılı olarak anlatılacaktır. Șimdilik, olağanïstii durum karşısında komün sisteminde yapılan șekillendirmeleri görelim : Bazı komünler fazla geniş ve yönetimi güç durumdaydı. Bun. lar, daha küçük birimlere ayrıldılar. Aynı zamanda, ademi merkeziyet sistemi savunuldu. Bütün kararların komün seviyesinde alınması yerine, komüinun altındaki birim olan ve üst-kooperatiflere

"Anna Louise Strong, "The Rise of Chinese People's Communes," s. 120-124. 
tekabül eden tugaylar, daha bağımsız duruma getirildi ve komünde toplanan arazi mülkiyeti bunlara verildi. Her zaman kârla çalışamayan kooperatiflerin çoğu, gıda üretimi ile doğrudan ilişkili olmadıkça, kapatıldı. Buna göre, faraza, çelik fırını kapatılabilirdi ama onarım diikkânları kalmalıydı. Ticaret de, komün seviyesinde bütünüyle merkezileştirilmiş olmaktan çıkarıldı. Tali işlerde ise serbest piyasa teşvik edildi. ${ }^{12}$ Söz konusu değișiklikler, bazı gözlemcilerin, komünlerin isimleri dışıda, artık var olmadıklarını ileri sürmelerine yol açtı. Eğer komün, tüm üretim araçlarını denetimi altında tutan merkezî bir planlama birimi olarak tanımlanırsa, böylesi bir sonuca kolayca varılabilir. Ne var ki, bu tanım fazla anlamlı görünmemektedir. Kimi komünler merkeziyetçilik ve serbest arz yolunda diğerlerinden daha çok ilerlemişlerdir. Önlemek üzere belirttiğimiz reformlarm yapıldığı bazı aşırılık ve hataların bütün komünlerde müsterek olduğunu düșïnmek yanlıştır. Örneğin, Șensi'deki Liu Ling komününde kaldırılacak ne serbest arz sistemi ne de özel arazi vard.. Burada komün, üst-kooperatiflerin hiç bir özel tartıșma ve karıșıklığı gerektirmeyen doğal genișlemesi olarak sayılmış görünmektedir. Bizzat Liu Ling köylülerince komünün yararları olarak ileri sürülenler ilkin, mahallî idarenin -hsiang- ekonomik durumdan sorumlu kadro ile birleștirilmesinin yönetim giderlerinde azalma olanağı vermesi; ikincisi, o zamana dek yapılabilenden daha büyük su koruması projelerini bașarmayı mümkün kılması; nihayet, komün refah fonundan, daha iyi sosyal güvenlik arz edilebileceğidir. ${ }^{13}$

Komünlerde, tarımsal vergileme ve pazarlama dïzenleri esasen değiştirilmeden bırakılmıştır. Vergi, rejimin ilk ylllarında o zaman normal saylan mahsulün \% 12'si civarında olarak saptanmıștı. Vergi, sabit oranlı olduğundan, üretimi genișletmeyi teşvik ediyordu. Şimdi ise, dönüm başına çıktı arttıkça, mahsulün daha küçük bir oranıdır. Devlet, ticaret acentaları vasıtasıyla sabit fiyatlardan hububat ve diğer zarurî maddeleri cebrî olarak satınalır. Komünlerin arz edecekleri mallar için önceden kotalar hazırlanır. Fiyatların sabitliği ve spekülatif manevralara konu olmaması, çiftçilere güven verir. Komün, kotasını doldurduktan sonra, dilerse daha fazla satma hususunda serbesttir. Diğer ürünler, serbest piyasaya müsaade edilen köy panayırlarında satılabilir.

\footnotetext{
12 Bu dönemde karşılaşılan güçlükler ile benimsenen çözüm yolları için Bkz: Edgar Snow, "The Other Side of the River" Bölüm 57.

${ }^{13}$ Bkz: Jan Myrdal, age.
} 
Komün sistemi, çok sayıda insana hareketlilik kazandirabilmesi yüzı̈̉nden, koșullarının var olduğu pek çok bölgede, açlığın önlenmesine şüphesiz ki yardum etmiştir. Komünler, hâlâ kuiçük çap teşebbüsler işletirler. Bunlar tuğla, gübre ve onarım yapar; bazen de araç ve aletler üretirler. Büyük çaplı sulama projelerini planlar ve gerçekleştirirler. Komünler, aynı zamanda, çağcll teknolojinin çiftçilere yayıldı̆̆ı bir köprü teşkil ederler. Genellikle her komüne tahsis edilmiş deneme istasyonları vardır. Bunlar, gübrelerin ve yeni tohum çeşitlerinin, mahalli şartlara göre yeni yöntemlerin tecrübe edildiği yerlerdir. Tüm bu yollarla, komünler işyeri yaratırlar ve kırsal bölgelerdeki hayat standardının yükselmesine yardım ederler.

\section{Sonuçlar ve Beklenenler}

Birinci Beş Yıllık Plan dönemi sonunda gayri safî tarımsal çlktının değeri -talî ve endüstriyel ürünler dahil- planlanan miktar1 hafifçe aşarak, 1952 fiyatlarıyla \% 24,7 artmıştır. ${ }^{14} 1952$ 'de 1,3 milyon ton olan pamuk üretimi, 1957 yilında 1,64 milyon tona yükselerek \% 28,8 artmıș; 1949 öncesi en yüksek üretim hacminin iki katına yaklașmıștır. Pirínç, buğday, patates ve akdarı gibi iri taneli hububat 1949'un çok düşük üretiminden 1952'nin 154 milyon tonuna çıkmıștır. Bu miktar, \% 19,8'lik yeni bir artışla 1957' de 185 milyon tona yükseldi. ${ }^{15}$ Hububat üretimi, hangi tahmin esas alınırsa alınsın, nüfustan dikkate değer ölçüde daha hızlı arttığından kiși başına tüketim, dönem boyunca yükseliyordu. Aynı şey, indirilmiş olduğu halde 270 milyon tonluk mahsulii ifade eden resmî rakamın, büyük olasılıkla, yine de çok aşırı bulunmasına rağmen 1958 yll için de söylenebilir. İleyen yıllar için fikir yürütmek üzere elimizde yalnız bilgi kırıntıları vardır. 1960'da mahsul 150 milyon tona kadar dïşmüş olabilir. 1961 yılı tahmini ise, küçük bir iyileşme ile 160 milyon tondur. Tarımsal durum 1962'de düzeldi ve günümüze dek her yll iyi mahsul alındığı bildirilmektedir. 1964 yılında hasılanın 200 milyon ton civarında olduğu açık. lanmıștır. ${ }^{16}$ 1967'nin ise bir rekor yılı olduğu ileri sürülmüş̧ür. Ne

\footnotetext{
14 "Ten Great Years," s. 118.

15 Ibid, s. 119-20.

${ }^{16}$ Bu konudaki kanıtların toplandığı kaynak olarak Bkz: R. M. Field, China Quarterly. Ocak-Mart 1968. 1960 ve 1961 yılı rakamlan Mao Çetung tarafindan Lord Montgomery'e yapılan açıklamalardan; 1964 için olanlar ise Çu En.Lay'in Edgar Snow'a verdiği bilgilerden edinilmiștir. Hububat mikta. rını tahmin etmek üzere birçok bağımsız girișimlẹrde bulunulmuștur. Birleşik Devletler'in Hongkong'daki tarım ataşesince yapılan tahmin bunlara
} 
nüfus ne de hububat çıtıtısı rakamlarm kesinlikle bilmediğimizden, kiși başına hububat tüketiminin varsayllı tahminini yapmak üzere bunların birini diğerine bölmek fazla yararlı bir is olarak düşünülemez. Bu biryana, eğer nüfus 1957 'den beri \% 2 hızla artmakta ve Financial Times muhabiri ${ }^{17} 1967$ yıl için mahsulï 230 milyon ton olarak tahmin etmekte isabetli ise, 1967 kişi bașına hububat tüketimi 1957'dekini hafifçe aşmış demektir.

Yukarıdaki tahmin ister doğru ister yanlış olsun, Çinlilerin tek gidası hububat değildir. Aynt zamanda, artan miktarlarda et, balık, meyva, sebze ve yumurta yemektedirler. Çoğu komünler, yaptıkları depclara balık stok etmektedirler. Öyle ki, ekseriya ilk kez olmak üzere komün üyeleri artık taze bahk yiyebilmektedir. Çin'i ziyaret edenlerin çoğunlukla gözlemledikleri hususlardan biri, faraza Sovyetler Birliği'nin aksine, şehir ve kasabalarda satılan taze meyva ve sebzenin bolluğudur. Sovyet plancıları, galiba, Çin gibi kalkınmanın çok daha geri bir așamasında bulunan ülkenin çözdüğù bu problemle hâlâ uğrașmaktadırlar.

Et, diğer az gelişmiş ülkelerde olduğu gibi Çin'de de, yoksullarca yılda en çok bir kez yenebilen bir lüks sayılmaktadır. Baş. Iıca, Kuzey'in öküzleri ile Güney'deki mandalardan meydana gelen biiyükbaş hayvanlar, yenmekten çok taşıma amaçlarıyla kullanılmaktadır. Başlıca et kaynağı olan domuz ise, eti için olduğu kadar yaratacağı gübre için de beslenir. Bununla birlikte, et halkm diyeti içinde giderek daha harcı âlem hale gelmektedir. Kurtuluş Savaşı öncesinde en fazla 78 milyon olduğu sanılan domuz sayısı 1952 yllinda 90, 1957'de ise 146 milyon olarak tahmin edilmiștir. Koyun ve keçi sayısı ise, Kurtuluş Savaşı öncesinin 63 milyonluk zirvesinden, 1957 yılında 99 milyona yükselmiştir. ${ }^{18} 1964$ yll sona ermeden, 200 milyon koyun ve keçi ile 150 milyon domuz vard.. ${ }^{19}$

\footnotetext{
bir ürncktir. Elde bașka srhhatli kanıtlar bulunmadığından, böylesi girişimlerin resmî raporlara dayanmadıkça muteber olmayacakları kanısında. yım. Nitekim, Birleşik Devletler tarım ataşesinin rakamlarn, 1961'den beri hayli düzelmiş bir yiyecek durumunu yansıtan seyyahların izlenimlerine karși düşmektedir. Atașe'nin rakamları, durumun eskisi kadar kötü oldü. ğunu ifade etmektedir. Öte yandan, resmî yada yarı resmî raporlar boşuna ügraştırıcı bir eksiklik içindedir. Faraza, Mao Çe-tung, doğru nakledilmișse, 150 milyon tonluk rakamına genellikle yapıldığı izzere, patatesi dahil edip soya fạsulyesini hariç mi tutmuştur?

17 Financial Times, 14 Termmuz 1968.

18 «Ten Great Years» s. 132.

1" Far East Trade and Development, Ekim 1964.
} 
Çin'in 1961'den beri glda maddesi ithal ettiği doğrudur. Bazen, Çin'in açlı̆̆ı önlemek üzere bu yola gittiği ileri sürülür. Ne var ki, bu iddia fazla dramatiktir. Ülke çapında genel bir kitlık olsaydı, ithal edilen birkaç tonluk buğday, durumda değişiklik yaratamazdı. Ithalata, kırsal bölgelerin üretimi azaldığında, Kuzey' in büyük şehirlerini besleme güçlüğünü yenmek üzere gidilmektedir. Çin bakımından, bư̆day üretimini artırmak pirinç üretimini artırmaktan daha güçtür. Gerçekte, bu ülke pirinç ve birçok başka gıda maddeleri ihraç etmektedir. Bu nedenle, ideal olarak bizzat yetiștirebilmesi beklenen gıda maddeleri için değerli dövizlerinin bir bölümünü ayırmak zorunda kalması Çin yönünden bir engelse de, bunun, şiddetli bir ihtiyacm açı̆̆a vurulması şeklinde yorumlanması fazla mübalağa etmek olur. Nihayet, Çin gibi, gıda maddesi ithal etmekle birlikte bunu ödeme olanağı bulunan ülkelerle, Hindistan gibi, bu maddeleri Birleșik Devletler'den bedava alan ülkeler arasında bir ayırım yapılmalıdır.

Ileride ne olacaktır? Çin gıda üretimini nüfus artışından daha hızlı yükseltebilecek midir? Söz konusu ülke, tarımsal çıtısı* nı şimdiye dek, mevcut tekniğin daha etkin kullanılmasıyla arttırmıştır. Daha çağcıl tekniklerin geniş çapta uygulanma zamanı ancak yeni gelmektedir. Örneğin, Çin kimyevî gübre endüstrisi aynı dönemde diğer her hangi bir ülkeden. daha hızlı geliştiği ve aynı zamanda büyük miktarda gübre ithal edildiği halde, bu ülkede ekili hektar başına uygulanan ortalama sunî gübre miktarı 1965 yılında, bitki beslenmesi terimleriyle, yalnız 67 kilogramdı. Buna karşılık, faraza Birleşik Devletler'de ortalama olarak 385 kilogram guibre uygulanmaktadır. Ancak, Birleşik Devletler'de toprak nispeten boldur. Bu yüzden, daha iyi bir karşılaştırma, toprağın nispeten kıt olduğu ve hektar bașına $356 \mathrm{~kg}$. gübre kullanan Hollanda ile yapılabilir. Yine Çin'in durumuna yakın olan Ispanya için söz konusu rakam 304 kg.'dır. Bunlara göre, Çin, her ne kadar halen hektar bașına Hindistan'm kullandığının üç katına yaklaşan miktarda gübre kullanmaktaysa da, benzer koşullar altındaki gelişmiş ülkelerin epey gerisinde bulunmaktadır. ${ }^{20} \mathrm{Bu}$ nedenle, mevcut ekili arazinin çıktısını artırma yönünden büyük bir potansiyel görülmektedir. Çin'in, ileri yöntemler uygulayarak, sonunda

\footnotetext{
${ }^{20}$ Bkz: Jung-Chao Lin, Journal of Farm Economics. 1965, Cilt 47. Tarımsal çıtıyı artırmak, şüphesiz yalnız daha çok gübre kullanma meselesi değil. dir. Japonya, yüksek tarımsal çıktı rakamlarnna ulaşabilmek için, ıslah edilmiş bazı bitki türlerini geliştirmek zorunda kalmıştır.
} 
İspanya'nınki kadar yüksek verimliliğe ulaşamaması için sebep yoktur.

Makineleşme de ancak yeni başlayabilmiştir. Toplamm yalnı küçük bir bölümünü oluşturan devlet çiftlikleri dışında, toprağın ișlenmesi yük hayvanlarıyla yapılır. Ekili arazinin ancak, \% 10'undan az bir kısmı traktörle işlenebilmektedir. Traktör sayısı 1949 yllinda 1000 'in altindaydı. Bu sayı her ne kadar 1962'de 100.000'e yükselmişse de, her bin hektarlık ekilebilir araziye yine 1'den az traktör düşüyordu. Makineleșme, uzun dönemli bir iş sayllmaktadır. Ilkin, ülkenin Kuzey yarısında yoğunlaşması planlanmıştır. İsgücünün bol, makineleşmenin teknik bakımdan daha gü̧ olduğu Güney'de ise, yarı-makineleșmeye ağırlık veriliyor. Yarı-makineleşme, el-arabalarına konulmak üzere tasarlanmış bilyalı yataklardan; mahalı̂i olarak yapılan, atların çektił̧i çok-sıralı yekelere kadar her şeyi kapsamaktadır. Bununla birlikte, sulama ve kurutmada pompalama istasyonlarının kurulmasılyla artan şekilde tam makineleșmeye gidiliyor. 1964 'de pompalama donatımının kapasitesi, 1957'dekinin 13 katına çıktı. ${ }^{21}$ Çin'de gıda bolluğu dönemine henüz erișilememiștir; yakın gelecekte de erişilemez. Halen epey iș başarılmışsa da daha yapılacak çok şey vardır. Endüstri, modern tarımın gerektirdiği tipteki araçları büyük miktarlarda yap. maya yeni başlamıştır. Tarımsal çıktıyı artırıcı teknik olanaklar geniştir. Geçmişte örneği olduğu üzere, sıkı çalışma ve kendini vakfetme oldukça, mevcut potansiyeli gerçekleştirmemek için se. bep yoktur. Ne var ki, Çin, eskisinden çok daha az olsa da doğal afetlere karșı hâlâ duyarlı bulunduğundan, beklenenlerin yapılabilmesi çok kolay değildir ve uzun bir zaman gerektirir.

\section{b) Endüstri}

Kurumsal Reformlar

Çin komünistleri, bürokrat kapitalistlerle millî kapitalistler arasında fark gözetmektedirler. Bürokrat kapitalistlerle, Komintang ve özellikle ünlü «dört aile»nin taraftarı olan büyük monopolcü ve yabancı çıarlarla işbirliği yapanlar kastedilmektedir. Millî kapitalist'le bağımsız bir endüstri kurmaya çabalayan ve ilerici bir güç olarak bakılabilecek küu̧ük işadamlan kastedilmektedir. Bunlar, çağcll endüstriyi yürütme tecrübesinden yoksun -komünist kadroda eksik bulunan değerli maharetlere sahiptiler. Bu yüzden, anıldığı adıyla, Yeni Demokrasi için yapılan program-

${ }^{21}$ L T C Kuo, China Quarterly, Ocak 1964. 
da, özel endüstrinin gelişmesi amacıyla millî kapitalistlerle anlaşma yapılması gereği belirtilmiştir. Millî kapitalistlerin mallarına el konulmayacak ama bunlar zamanla sosyalist sektöre çekilecekti.

Bir yandan Komintang ileri gelenlerinin işlettikleri teșebbüslere el koyup öte yandan bürokrat kapitalist sayılan çıar grubunca yürütülenleri tazminat vermeksizin devletleștirmekle, yeni hükümet endüstride güçlü bir durum kazand. Ayrıca, iş̧̧ileri işten atmalarmı kabul etmeme gibi yollarla yabancı firmaların durumunu güçleştirerek, bu şirketleri varlıklarm devlete devretme zorunda bıraktı. Yeni rejimin daha ilk yllında endüstrinin \% 35'i sosyalist sektöre aitti. Bu sektör, sonraki ylllarda, kısmen özel endüstriden çekmek, kısmen de diğer endüstri kollarından daha hızlı gelişen sermaye malları sektöründe devlet mülkiyetini yogunlaştırmak suretiyle, hızla genișledi.

Özel endüstrì sektörünün sosyalizme dönüșümü; alt-kooperatifler ve üst-kooperatiflerin gelişimine paralel olarak iki aşamada gerçekleşti. Önce, hükümet denetiminin yoğunlaşması ölçüsünde, birçok firmalar üretimlerini hükümetle yaptıkları anlaşmalara göre ayarlamaya bașladılar. 1952'de, endüstrinin yaratılan değer yönünden \% 22'si bu durumdaydı. Hükümet, aynı zamanda özel sektörle karma teşebbüsler kurmaktaydı. Böylesi teșebbüsler 1955 yilınm ikinci yarısı ile 1956 yilında hızla arttı. Tarımda kooperatifleșme yolunda yapılan baskıların hiz kazanması da aynı zamana rastlar. Karma teşebbüs sisteminde özel sektörün tüm aktif kıymetleri temin etmesine rağmen bütün denetim devlet elindeydi. Kâr, başlangıçta üçe ayrılırdı. Bir kısmı vergi olarak devlete gider, bir kısmı dağıtılmadan bırakılır, kalanı ise temettü olarak ortaklara ödenirdi. Teșebbüslerin eski sahipleri genellikle yönetici olarak alıkonur; bu durumda kendilerine ayrıca maaş da verilirdi. Sonraları, kârı bölüștürme sistemi terkedilerek, kapitalistlere mallarına biçilen değer üzerinden sabit bir faiz ödenmeye başlandı. 1956 yılında özel endüstri sektörü ortadan kalktı. Endüstriyel çıktının \% 67,5'ini sosyalist sektör, kalanımı ise karma teșebbüsler yaratıyordu.

Buradaki endüstri terimi, küçük sanatları kapsamamaktadır. Küçük sanat erbabı, kapitalist değil; köylüler gibi, münferit ekonomilere ait sayılmıştır. Bunlar, yine köylüler gibi, kooperatifler halinde örgütlenmişlerdir. Serbest ticarette de paralel bir dönüşïm meydana geldi. Toptan ve perakende ticaret, devlet sektörü- 
ne yada kooperatiflere kazandırıldı. Birinci Beş Yıllık Plan dönemi sonunda serbest ticaret ihmal edilebilir durumdaydr..2

Özel endüstrinin sosyalizasyonu pürüzsüz șekilde ve büyük güçlüklerle karşılaşılmaksızın başarlmış görünmektedir. Şüphesiz ki, özel müteșebbisler, günden geceye ateşli sosyalistler haline gelmediler, Öte yandan, çalșmaları da hükümetçe daima bütünüyle yeterli bulunmadı. Örneğin, 1951'de rüșvet, vergiden kaçınma, devlet malını çalma, dolandırıcılık ve devlet sırlarını elde etmeye karș1 $5^{\prime}$ li bir kampanya -Five Antis- açıldı. Bununla beraber, müteșebbisleri yeni hükümetle işbirliği yapmaya yönelten nedenler de vardı. Işadamlarmın, Komintang yönetimi altındaki durumları iyi degildi. İdarede bozulma, ağır vergileme ve enflasyon iş çevirmeyi güiç, hatta gözetilen bir azınlık dışındakiler için yıkıcı duruma getirdi. Komünistler, kapitalistleri ulusal ekonominin kurulmasına yardıma çăgırırken, bunların yurtseverlik ve ulusal gururlarına seslendi. Ayrıca, is adamlarmnn hayatlarından mahrum bırakılmayacağı da açıkça belirtildi.

\section{Siyasalar ve Sonuçları}

Birinci Beș Yıllık Plan ve 1958-60 Büyük Hamle ylları boyunca Çin'in endüstriyel yapısında önemli değișmeler oldu. Çă̌s. cll endüstri küiçük sanatlardan daha hızlı gelişerek toplam endüstriyel çıktının giderek artan bir bölümünü meydana getirdi. Ağgır endüstri, planlandığı üzere, hafif endüstriden daha hızlı gelişti. Söz konusu endüstri, daha 1957 yllında, toplam endüstriyel çıtının \% 48'inden fazlaydı. Bu oran, 1958'de \% 57'nin üzerine çıtı. 1960 yılında da \% 60,5'e yüksselmesi planlanmıştı. Endüstri, aynı zamanda, tarım karșısındaki önemini de artırıyordu. Bir tahmine göre, safî millî hasılanın 1952'de \% 47,9'unu oluşturan tarım, 1957 yilında \% 39, 1958'de ise yalnız \% 33,9'unu yaratmıştır. Buna karşlık, 1952'de safî millî hasılanın \% 11,5'ini olușturabilen modern endüstri, toplam içindeki payın 1959 yllında \% 25'e çıartmıştır. Modern endüstrinin, küçük sanatlar ve inşaatla birlikteki payı ise $\% 20,7$ 'den \% 36,3'e yükselmiștir. ${ }^{23}$

Endüstrinin -küçük sanatlar dahil- gayri safî çıtıtı değeri, Birirıci Beș Ylllkk Plan döneminde, resmî rakamlara göre, \% 128,4 oranında artmıştır. $\mathrm{Bu}$, ortalama olarak \% 18'lik yıllık artış demektir. Batı'daki bilginler, endeks olarak gayri safî çıktı değerini

${ }^{22}$ Sosyalist sektörün genişlemesi hakkında Bkz: «Ten Great Years» s. 38-39.

${ }^{23}$ Cho-Ming Li, China Quarterly. Ocak-Mart 1964 s. 16-18. 
kullanmanın, gelişmeyi olduğundan fazla göstereceğini ileri sürmüşlerdir. Bilginler, kendilerince daha gerçekçi bir sonuca ulaşmak amaciyla resmî rakamlarda başka düzeltmeler de yapmaya çalıștılar. Burada, söz konusu düzeltmelerin haklı olup olmadığı tartışmasına girmeyeceğiz. $\mathrm{Ne}$ var ki, bütün düzeltmeler yapılsa bile, artış hızları yine de çok yüksek çıkmaktadır. Nitekim, Birinci Beş Ylllık Plan için Batı'da yapılan üç tahminden en düşüŭüi $\%$ 85,9'luk bir artıșı ifade ediyor.

Çin'liler, 1957-60 arasında toplam \% 177,3'lük bir artıșı ifade etmek üzere 1958, 1959 ve 1960 yılları için sırasıyla \% 66,3, \% 39,2 ve \% $29^{\prime} l u k$ artışların olduğunu iddia ettiler. Bu dönem için yapılan yabancı tahminler ise dikkate değer ölçüde düşüktür. Örneğin, 1958 için\% 20-30, 1959 için \% 30 civarındadır. Yine 1957-60 dönemi için bir diğer yabancı tahmin ise \% 82,9'luk bir artıştır. Anlaşmazlığın, çağcıl endüstrinin çıktısı değil; daha çok, yabancı gözlemcilerin, resmî rakamlarla iddia edilenden daha düșük hızla geliştiğine inandıkları küçük sanatlar çıktısı üzerinde olduğu gözden kaçırılmamalıdır. En kötümser yabancı tahminleri kabul edip Çin'in çok düşük bir gelişme seviyesinden harekete başladı̆̆ı gerçeg̛ini de gözönüne aldığımıda, bu dönem zarfında endüstriyel çıktının istisnaî bir hızla arttığı açıkça ortaya çıkar. ${ }^{24}$

Çin, çelik endüstrisinde olduğu gibi, yalnız mevcutları genişletmekle kalmamıs, yeni endưstriler de yaratmıştır. Kimyevî gübrelerden daha önce söz edilmiști, bunun dışında bașka endüstriler de vardır. Araba, kamyon, lokomotif, çeşitli büyüklïkte traktörler, komple biçer-döğerler, 10.000 tona kadar gemiler ve geniş bir makine grubu imâli $1960^{\prime}$ a kadarki dönemde yapımına bașlanmıș olan ileri mamullerden bazılarıdır. Yenileşme hızı, sonraki yıllarda da azalmamıştır. Çin'in 1967 yılında hidrojen bombasını patlatması, çeșitli ileri teknolojilere olan hakimiyetini gösterir. Askerî alan dışında, mal çeşitliliği devamlı artırılmıștır. Orneğin, son zamanlarda plastik endüstrisi kurulmuştur. Çin, bazı hallerde, Batı'dan komple makine ithalini hâlâ kârlı bulmaktaysa da, modern donatımın geniş bir bölümünde kendi kendine yetmektedir. Çin endüstrisinin böylesi bir hızla gelişmesini sağlayan etkenler nelerdir? Çin, 1960 yılına kadar, Sovyetler Birliği'nden önemli hacimde yardım almıștır. İki büyük kalkınma istikrazı yapılmış; Sovyetler Birliği birçok büyük modern projenin yapımına yardımı üstlenmiştị. 1957 sonunda bu projelerden $68^{\prime} i$,

4 Ibid, s. 14 . 
1960 sonunda ise 154 '̈̈ tamamlanmıştır. Çinlilerin yatırım gayretlerinin ancak küçük bir bölümünü temsil ettiğinden, önemli olan Sovyet yardımının gerçek tutarı değildir. Yardımın gerçek önemi büyük kısmının Çin'in o zamana dek hiç bir tecrübesinin bulunmadı̆̆ı modern yöntemler hakkında teknik yardım şeklinde gelmesidir. İște bu yüzden yardımın 1960 temmuzunda Çin-Sovyet anlaşmazlığı sonucu kesilmesi ve Sovyet teknisyenlerinin krokilerini de alarak çekilmeleri, Çin ekonomisi için ciddî bir darbe olmuștur. ${ }^{25}$ Söz konusu tarihten bu yana, Çin kimseden yardım almamıș; aksine, bazı ülkelere yardım yapmıştır. Sovyetler Birliğine olan bütün borçlar 1965'ten önce ödendi. Bununla birlikte Çin'liler, yardımın kesilmesi șeklindeki kötülüğün kendi kendine dayanmaya zorlaması yüzünden, sonunda iyiliğe dönüştüğünde karar kıldılar. Ayrıca, yalnız kendi kaynaklarıyla kaldıklarında, mahallî koşullara yakın olmayan yabancı uzmanların salık verdiğinden daha iyi çözüm yollarının bulunabileceğini gördüler,

Endüstriyel ilerlemenin temel nedeni, bizzat Çin'lilerin kendi çabalarıydı. Ekonomideki tasarruf oranı sürekli olarak yükseltildi. Bir yabancı tahmine göre 1950 de gayri safî millî hasılanın $\%$ 5,5'i olan gayri safî sabit yatırımlar, Birinci Beş Yıllık Plan döneminde \% 17,9'a, Büyük İleri Hamle yllarında ise \% 25 civarina çıkartılmıștır. ${ }^{26}$ Bina, makina ve benzeri yatırımlar yanısıra, Çinliler insangücüne de yatırım yapmıșlardır. Geniş öIçüde artırılmış bir nitelikli insangüicü arzı, endüstrideki fizik genişlemenin vaz geçilmez tamamlayıcısıyd. Bilgin, teknolojist ve her çeșitinden okumuş insanların azlığı az gelişmiş ülkelerin ilerlemesindeki başlıca engellerden biridir. Çin'in ihtiyaçlarına en uygun eğitim biçimi halen Kültür Devrimi çerçevesinde tartışlan temel konulardan biri olmakla beraber, 1949'dan beri sayıca ulaşılan bașarılar şüphe götürmez. Çin'in 1949-1958 arasındaki on ylla, yüksek öğrenim enstitülerinden 130 bini mühendis olmak üzere 431 bin öğrenci yetiștirdiği bu konuda bir örnek olarak verilebilir. Bu, önceki yirmi yılda yetiştirilebilenlerin iki katından da fazladır. ${ }^{n}$

\footnotetext{
25 Sovyet yardımının Temmuz 1957'de 750 milyon sterlin'e ulaștı̆̆ söylenmektedir. Bkz: Hughes and Luard, age, s. 84. Ancak, bu miktarm tamamı hibe deł̧̣̂l ođdünç olduğundan 'yardım' hayli yanıltıcı bir terimdir. Sovyet cömertliğinin derecesi ödünç verme şartlarının ayrıntılı şekilde incelenmesiyle değerlendirilebilir ki, bu konuda doyurucu bilgi yoktur. Yine de dikkate değger bir cömertliğin söz konusu bulunmaması olasıdır.

${ }^{2 t}$ W. W. Holister. China Quarterly. Ocak-Mart 1964, s. 40.

${ }^{27}$ «Ten Great Years, $\$$ s. 187.
} 
Rakama vurulamamakla beraber, iyileștirilen sağllk koşullarıntn ilerleme yolundaki katkısı da gözden kaçırılmamalıdır. Kolera, tifo, veba gibi bulaşıcı ve öldürücui hastalıkların kökünün kazınması; sistosomiyasis * gibi güç azaltanlarınsa denetlenmesi, genel refahı gözle görülür biçimde artırmıştır. Toplum sağlığının daha iyi korunması da kalkınmaya yardımcıdır. Zira öldürücï hastalıklar ihtiyar ve zayıflar kadar genç ve güçlüleri de götürebilirse de, midelerinde kurt olmıyan insanların daha sık1 ve etkili çalışabilecekleri açıktır. 1949'dan beri yetişen doktorların millî gelir artışındaki payları, ölçülemezse de büyüktür.

Birinci Beş Yıllık Plan'ın amacı, geniş bir endüstriyel yapının temellerini olanak ölçüsünde hızla atmaktı. Bu amaçla, devlet bütçesinde sermaye malı endüstrilerine öncelik verilmesi kararlaștırıldı. Yatırım fonlarının büyük kısmını çekecek olan bu endüstrilerin tüketim malları endüstrilerinden daha hızlı gelişmeleri de planlanmıștı. Müstakbel gelişmenin temelini atmak amacıyla, tüketim malları miktarı da artırıldı. Çinliler, aynı derecede müfrit olmamakla beraber Sovyetler Birliği'nin öncülük ettiği kalkınma stratejisini uygulamaktaydılar. Devlet bütçesinin tarıma ayrılan kısmı nispeten azdı. (Mamafih, köylülerce yapılan yatırım devlet bütçesi dışındaydı). Planlama, başlangıçta Sovyet modeline uygun olarak hayli merkezîleştirilmişti. Önemli hedeflerin tümü, Pekin' de çeşitli endüstrilerden sorumlu bakanlıklarca saptanırdı. Ancak, bu yöntem, Çin gibi büyük bir ülkede bozukluklara ve kayıplara yol açtı. Bu yüzden, 1957 sonlarında, endüstri denetiminde geniş ölçüde ademi merkeziyete gidildi. Tüketim malı endüstrileri mahallî makamların denetimine brrakıldı. Merkezî makamlar ekonominin geri kalan kesimi iuzerindeki genis yetkilerini ise, sermaye malı endüstrilerini doğrudan doğruya denetleme; yatırım oranını saptama, hammaddelerin tahsisi, ücret ve istihdam seviyesinin tespiti gibi yollarla kullanmaktaydrlar.

Bu reform, mahallî ve kişisel insiyatiflere ağırlık veren Büyük İleri Hamle için bir hazırlık görevi yapmıș oldu. Tüm ülke halkı, örneği görülmedik çabalar harcamaya çağrıldı̣. Ikinci Bes Ylllık Plan'da öngörülen hedefler bir yana birakılarak daha ilerileri getirildi. "Her iki ayağı üzerinde birden yürümek» bu dönemi, daha doğrusu Çin kalkınmasının gerçek biçimini betimleyen

* Bilharzia adıyla da anılan bu tropikal hastallk Mısır, Afrika, Arabistan ve Irak'ta yaygndır. Sistosomiya denilen bakterinin vücuda girmesiyle başlar (Ç. N.). 
bir parolaydı. Adı geçen parola, Çin'in kaynaklarının tamamını kullanması anlamına geliyordu. Eğer modern endüstri, her hangi bir ihtiyacı karşılıyamıyorsa, geleneksel yöntemler kullanılmalıy. d. Böyle yapılması, sermaye ve modern teknoloji arzının kıt bulunduğu Çin yönünden anlamlıdır. Șüphesiz, böylesi bir hamle, görüldǚ̆ü üzere üretimde büyük artışlar yaratmıșsa da karıșılık ve güçlüklere de yol açmıştır. Örneğin, ulaștırma șebekesinin, geniş ölçüde artan mal akımıyla başa çıkmaktaki yetersizliği sıkça ortaya çımıstır. Şüphesiz mal akımının genişleme hızı ilelebet sürdürülemeyecek; ulaşım şebekesini takviye etmeye zaman vermek üzere, kaçınılmaz bir yavaşlama olacaktı. $\mathrm{Ne}$ var ki, sözünü etmiș bulunduğumuz tarmsal güçlüklerin kapsamı belirgin hale gelince, yeni bir siyasa ortaya atıld. Artık, tarım ulusal ekonominin temeli, endüstri ise öncü sektörü sayılacaktı. Bu ise uygulamada, endüstriyel yatırımların büyük bölümünün doğrudan doğ. ruya tarımın ihtiyaçlarına yöneltilmesi demekti. Bu yola gidilmesi, mutlaka ağır endüstriye öncelik verme siyasasından dönme anlamına gelmiyordu. Zira, kimyevî gübre ve tarımsal makine yapı$\mathrm{m} 1$ gibi endüstriler ağır endüstri sektörüine dahildi. Sadece, gıda üretiminin artmasına doğrudan doğruya yardım etmediğinden öncelikleri azalan endüstri dalları yönünden, bu anlama gelmektey. di. Büyük Îleri Hamle döneminde kısmen kırsal bölgelerde küçük . ölçekli endüstrilerin kurulması kısmen de kasabalara akın nedeniyle, endüstriyel işgücuii çok fazlalaşmıştı. Bunun büyük çoğunluğu, yeniden tarıma yöneltildi. Ayn zamanda, köylüleri ürünlerini pazarlamaya teşvik etmek üzere, kırsal bölgelere tüketim malları arzını artırıcı tedbirler alındı. Bu siralarda Sovyet yardımının da kesilmesiyle, kendi kendine dayanma parolası benimsenmişti.

Bu siyasa değișiklikleri, kimi gözlemcileri evvelki önceliklerin hatalı olduğunu düșünmeye yöneltti. Iddiaları şöyledir: Çin komünistleri $1960^{\circ}$ a kadar endiustriyi tarımın zararına genişletmekte doğmatik olarak ısrar ettiler. Sonradan tarımsal afetlerin çımas1, komünistleri yeni bir değerlendirme yapmaya zorladı. Böylece, Büyük İleri Hamle bir yana bırakılarak daha gerçekçi siyasalar benimsendi. Çin liderlerinin 1959 ve 1960 tarımsal buhranlarına karşı koymakta yavaş davrandıkları, pek çok kaynağın gıda üretiminden çekilmesine göz yumdukları kabul edilebilir. Fakat, bundan, evelki önceliklerin hatalı olduğu sonucu hiç bir şekilde çıarılamaz. Eğer bir endüstri temeli kurulmasaydı, tarım için işgücü ve toprağ̆ın çıktısını artırmak üzere gerekli çağcıl çıktıların 
temini şimdiki gibi mümkün olamazdı. Bu yüzden, önceki dönemde seçilen yatırım modelinin mevcut kaynakların en iyi kullanmin yansıttığ hakh olarak savunulabilir.

1960 sonrası için elde çok az istatistik bulunduğundan, endüstrinin toptan gelişmesine ait tahminler fazla değerli değildir. Yine de, çıtı hacminin tarımsal buhranm yol açtı̆̆ı duraklamadan kurtularak 1962 yllında eski seviyesine ulaștı̆ğ ve o zamandan beri de artmakta olduğu anlaşılmaktadır. 1966'da bașlayan Kültür Devrimi'nden sonra basının karışıklıklar doğduğtu yolunda kamu oyuna maledilen raporlarına rağmen, karşı etkilerin bütünüyle mahallî ve geçici olduğu görülmektedir. Bir bütün olarak ekonomi, endüstriyel üretim yıldan yıla artmak üzere, muntazaman işlemiştir. Gerçekte, Çin'liler bu dönemde başlıca sektörlerde büyük ilerlemeler olduğunu ileri sürmektedirler.

\section{SONUÇ}

Çin liderleri, ekonomik kalkınmayı başarmak için büyük çabalar gerektiğini gizlemediler "Başkan Mao Çe-tung'dan Iktibaslar»ın bir bölümüne «Ülkemizi çalışkanlık ve tutumluluk yoluyla inşa etmek" başlığının verilmesi dikkate değer bir noktadır. Dikkate değer diğer bir nokta ise, Çinlilerin, endüstrileşmeyi yığınların hayat standardını yükselterek bașarmalarıdır. Böyle olduğu, Çin'i devrimden önce taniyan ve son yillarda orada bulunmus olanlarca bilinmektedir. Söz konusu başarı, kısmen daha âdil bir gelir dağılımı kısmen de tüketim malları arzının artırılmasıyla elde edilmiştir. Şehirlerde, temel ihtiyaçlar için tayınlamaya gidilmektedir. Ancak, bu yola, hızlı kalkınma sürecinde kaçımılmaz şekilde beliren enflasyonist baskıları önlemek üzere bașvurulmaktadir.

Çin'liler, maddî müşevviklerin önemini daima kabul etmekle birlikte, diğer müş̧evvikleri tahrik etmek suretiyle gelir eşitsizliğini asgariye indirmeye çalıștılar. Bu çaba gerçekçi bulunmamıştır. Ne var ki, önceleri yoksulluk içinde yaşıyanların hayat seviyelerini yükseltmek o denli önemli sayılmıștır ki, bu uğurda toptan kalkınmadan fedakârlık edilebilìr. Kaldı ki, Çin'liler, ken. di yöntemlerinin, alıșılanın aksine, gelir eşitsizliğini artırarak basarılabilecek olandan daha hızlı bir gelişmeyi sağhyacağını iddja etmektedir. Fedakârlıklar, eşit olarak paylaştırıldığında, bunlara daha gönülden katlanılabilir. Maddî müșevvikler de fazla önem- 
senmezse, tüketim kısllarak daha çok tasarruf olanağı yaratılabilir.

Ortalama bir Çinli yönünden hayat standardındaki iyileşmeden belki de daha önemli olan, ekonomik güvenliğe ilk kez kavuşmuş olmasıdır. Yiyecek, giyecek, barınak, tıbbî bakım gibi hayatın temel ihtiyaçları yalnız şehirlerde değil, komünler vasıtasıyla kırsal bölgelerde de sağlanmıştır. Yine de Çin'in ekonomik ba. kımdan ileri ülkelere yetişmesi için çok zaman gereklidir. Halen, endüstriyel üretim hacmi yönünden, faraza Ingiltere'den geridir; toplam değil de kişi başına endüstriyel üretiminin İngiltere seviyesine gelmesi ise çok daha fazla zamanı gerektirir. Herşeye rał̆men, refaha giden uzun yürüyüşüin ilk adımları atılmıștır. 